\title{
Living on the edge: single-species dominance at the Pakistan oxygen minimum zone boundary
}

\author{
Rachel M. Jeffreys ${ }^{1, *}$, Lisa A. Levin ${ }^{2}$, Peter A. Lamont ${ }^{3}$, Clare Woulds ${ }^{4,5}$, \\ Christine R. Whitcraft ${ }^{2,6}$, Guillermo F. Mendoza ${ }^{2}$, George A. Wolff ${ }^{1}$, Gregory L. Cowie ${ }^{4}$ \\ ${ }^{1}$ School of Environmental Sciences, University of Liverpool, 4 Brownlow Street, Liverpool L69 3GP, UK \\ ${ }^{2}$ Center for Marine Biodiversity and Conservation and Integrative Oceanography Division, \\ Scripps Institution of Oceanography, 9500 Gilman Drive, La Jolla, California 92093-0218, USA \\ ${ }^{3}$ Scottish Association for Marine Science, Dunstaffnage Marine Laboratory, Oban, Argyll PA37 1QA, UK \\ ${ }^{4}$ School of GeoSciences, University of Edinburgh, Edinburgh EH9 3JW, UK \\ ${ }^{5}$ Present address: School of Geography, University of Leeds, University Road, Leeds, West Yorkshire LS2 9JT, UK \\ ${ }^{6}$ Present address: Biological Sciences, California State University Long Beach, 1250 Beltflower Blvd, Long Beach, \\ California 90840-3702, USA
}

\begin{abstract}
Oxygen minimum zones (OMZs) are naturally occurring, low-oxygen water masses that create hypoxic conditions where they impinge on the seafloor. Their lower boundaries are characterised by elevated densities of hypoxia-tolerant fauna and an abundant food supply. The polychaete Linopherus sp. nov. (Amphinomidae) is the dominant taxon at the Pakistan margin (PM) lower OMZ, at near suboxic dissolved oxygen (DO) concentrations of 5 to $8 \mu \mathrm{M}$. We explored the response of Linopherus sp. nov. to gradients in oxygen and organic matter (OM) availability from depths of 700 to $1100 \mathrm{~m}$ during the inter- and late monsoon periods. Linopherus sp. nov. was present from 800 to $1000 \mathrm{~m}$, and highest densities were found at $850 \mathrm{~m}$. Population size structuring was evident and smaller individuals were present at depths of lowest DO concentrations. Linopherus sp. nov. showed morphological adaptation to low DO, and respiratory surface areas were significantly larger in worms at sites of lowest DO concentrations. Stable carbon isotopes $\left(\delta^{13} \mathrm{C}\right)$ revealed that Linopherus sp. nov. feeds mainly on sedimentary OM while enriched $\delta^{15} \mathrm{~N}$ values suggest that Linopherus sp. nov. also utilises predation as a foraging strategy. Lipid biomarkers indicate an omnivorous lifestyle, in which Linopherus sp. nov. uses phytodetrital, bacterial and invertebrate/carrion food sources. Pulse-chase experiments demonstrated that Linopherus sp. nov. consumes phytodetritus and contributes significantly to OM processing, potentially altering $\mathrm{OM}$ quality and thus the availability of food resources to the benthic community. Severe oxygen stress leads to single-species dominance, which in turn simplifies macrofaunal ecosystems and thus reduces trophic complexity.
\end{abstract}

KEY WORDS: Oxygen minimum zone $\cdot$ Hypoxia $\cdot$ Single-species dominance $\cdot$ Organic matter processing $\cdot$ Linopherus $\cdot$ Stable isotopes $\cdot$ Lipid biomarkers

\section{INTRODUCTION}

Mid-water oxygen minimum zones (OMZs), water masses where dissolved oxygen (DO) concentrations fall below $22 \mu \mathrm{M}$, are widespread hydrographic features in the world's oceans (Kamykowski \& Zentara 1990, Helly \& Levin 2004). Oxygen depletion results from a complex set of interactions that starts with nutrient injection via upwelling and intense surface water production. This is exacerbated by limited ventilation within the water column owing to stratification and isolation of older water masses (Sarmiento et al. 1988). The interception of mid-water OMZs onto continental margins results in benthic hypoxia and 
currently affects over 1 million $\mathrm{km}^{2}$ (approximately $2 \%$ ) of margin seafloor (Helly \& Levin 2004). Climate models and observational data show an expansion of mid-water OMZs in the world's oceans, resulting from global environmental change, e.g. temperaturedriven changes (i.e. declining oxygen solubility), altered ocean circulation patterns, increased stratification, changes in biological production, variations in biological oxygen demand and altered remineralization rates (Bopp et al. 2002, Goes et al. 2005, Stramma et al. 2010). Concurrently, the extent and frequency of coastal hypoxia is also increasing as a result of anthropogenic forcing (Diaz \& Rosenberg 2008, Diaz et al. 2009, Rabalais et al. 2009).

Field programs have been carried out to survey benthic communities inhabiting OMZs throughout the world's continental margins, e.g. West Africa (Zettler et al. 2009), Oman (Gooday et al. 2000, Levin et al. 2000), Pakistan (Gooday et al. 2009, Hughes et al. 2009), India (Ingole et al. 2010, Hunter et al. 2011), Peru (Levin et al. 2002) and Chile (Gallardo et al. 2004, Palma et al. 2005). The majority of these investigations are based on transects where stations are spaced fairly widely apart (e.g. Hughes et al. 2009). Such studies, when they include an experimental component, have provided insight into ecosystem processes and function, e.g. Woulds et al. (2007, 2009), Andersson et al. (2008). From these field programs the lower boundaries of OMZs have been identified as particularly dynamic settings where animal densities can be remarkably high, but diversity is often low (Levin 2003). This is true of both the water column (Wishner et al. 1995, 1998, 2000) and the seabed (Levin et al. 1991, Wishner et al. 1995, Gooday et al. 2009).

A number of taxa have been identified as being particularly tolerant to permanent hypoxia in the deep sea. These include some spionid, cirratulid and cossurid polychaetes (Levin \& Edesa 1997, Lamont \& Gage 2000), glochinemid nematodes (Neira et al. 2001, 2005), ampeliscid amphipods (Levin 2003) and some oligochaetes (Levin et al. 2003). However, sampling designs have yielded few autecological studies that investigate in detail the adaptations or population biology of species within OMZs. Exceptions are the detailed studies of the pelagic copepod Lucicutia grandis by Wishner et al. (2000), the Humboldt squid Dosidicus gigas by Rosa \& Seibel (2010), the benthic mud-ball forming cirratulid Monticellina sp. by Levin \& Edesa (1997) and the spionid Paraprionospio pinnata by González \& Quiñones (2000). Responses to the physiological constraints of OMZs have also been documented in several species of calanoid copepods via ontogenetic zonation (Wishner et al. 2000, 2008, Loick et al. 2005, Criales-Hernandez et al. 2008).

Recent studies across the Pakistan margin (PM) OMZ have revealed the rarity of infaunal macrofauna within the OMZ core (300 to $600 \mathrm{~m}$, Hughes et al. 2009). Polychaetes dominate in the lower OMZ transition zone (750 to $1100 \mathrm{~m}$ ) and account for 61 to $100 \%$ of the macrofauna. One undescribed, new species of amphinomid polychaete, Linopherus sp. nov., constitutes over $80 \%$ of total macrofaunal abundance at some lower OMZ sites (Levin et al. 2009b). From high-resolution sampling across sharp oxygen gradients in different seasons it should be possible to infer the ways in which oxygen and food supply affect population and community structure at the PM.

The present study focuses on the autecology of Linopherus sp. nov., the dominant infaunal macrofaunal organism within the lower OMZ on the PM (700 to $1100 \mathrm{~m}$, Levin et al. 2009b) and uses it as a model for exploring larger fundamental questions regarding ecosystem functioning within OMZs. Because this species exists over a gradient of critical oxygen thresholds (5 to $8 \mu \mathrm{M}$ ) and ranges from being almost the only macrofaunal species present at its lower oxygen limits to being rare among many others at its lower depth limit, we can explore how oxygen influences ecosystem processes via species activities. We ask: (1) How does the lower OMZ environment (i.e. oxygen and organic matter [OM] quantity and its associated biotic thresholds) influence the distribution and size structure of Linopherus sp. nov.? (2) Does Linopherus sp. nov. exhibit morphological or ecological adaptations that allow it to be so successful in low oxygen environments? (3) How does Linopherus sp. nov. affect biodiversity and ecosystem functioning, defined here as OM processing, within the lower OMZ transition zone?

In order to address these questions, we present both new data and synthesize previously published data to provide an integrated view of how Linopherus sp. nov. functions across the lower OMZ. The new data presented here for Linopherus sp. nov. are (1) detailed information on the size distribution including biomass (wet weights of individuals) and size (length estimated from number of chaetigers), (2) detailed analyses of respiratory structures, (3) video footage of the species in its natural habitat and (4) stable isotope (carbon and nitrogen) and lipid data to elucidate the trophic ecology. These new data are set in the context of, and interpreted using, previously published information regarding the abundance and distribution of both the macrofauna and Linopherus sp. nov., the environmental conditions at the lower 



Fig. 1. (A) Location of the Pakistan margin working area and (B) detail of the lower oxygen minimum zone transect. Grey circles indicate depths sampled by megacorer and black circles indicate depths where in situ oxygen measurements were obtained in addition to megacores

OMZ boundary (i.e. DO, organic carbon and nitrogen, total phytopigments and grain size) (Levin et al. 2009b), sediment structure and burrow activity (Levin et al. 2009b), and OM processing by Linopherus sp. nov. determined from shipboard and in situ pulse-chase experiments using ${ }^{13} \mathrm{C}$-labeled diatoms (Woulds et al. 2007).

\section{MATERIALS AND METHODS}

\section{Study area}

The study area was located north of the Indus canyon, at the PM, Arabian Sea, around $23^{\circ} 33^{\prime}$ to $22^{\circ} 66^{\prime} \mathrm{N}, 65^{\circ} 83^{\prime}$ to $66^{\circ} 83^{\prime} \mathrm{E}$ (Fig. 1A). The Arabian Sea is characterized by steep gradients in bottomwater oxygen and organic carbon concentrations (Cowie 2005). Seasonally reversing monsoons lead to upwelling of nutrients and high primary production; $\sim 5 \%$ of the total global primary production occurs in the Arabian Sea (Qasim 1982, Pfannkuche \& Lochte 2000). This elevated primary production leads to some of the highest recorded particle fluxes to the deep ocean $(\sim 3000 \mathrm{~m})$, ranging from 0.1 to $190 \mathrm{mg}$ $\mathrm{m}^{-2} \mathrm{~d}^{-1}$ (Haake et al. 1993, 1996, Honjo et al. 1999). Detailed information on the hydrography and sediment geochemistry of the study area is given in Cowie \& Levin (2009) and references therein. Both oxygen concentration and food availability (sedimentary organic carbon) are known to affect the abundance and diversity of foraminifera, macrofauna and megafauna at the PM (Hughes et al. 2009, Larkin \& Gooday 2009, Levin et al. 2009b, Murty et al. 2009). In turn, the abundance and biomass of fauna at the PM influence sedimentary OM quality through their feeding processes (Jeffreys et al. 2009a). These effects are more pronounced at the lower boundary of the PM OMZ (1000 to $1300 \mathrm{~m}$ ), where there is a balance between a rich food supply and relief from oxygen limitation, resulting in high densities of deposit- and filter-feeding fauna removing labile $\mathrm{OM}$, i.e. polyunsaturated fatty acids from the water column and sediments by molecular filtration (Jeffreys et al. 2009a, Levin et al. 2009b, Murty et al. 2009). The dominant macrofaunal organism at the PM lower OMZ transition zone/boundary (700 to $1100 \mathrm{~m}$ ) is Linopherus sp. nov. (Levin et al. 2009b), the subject of this study.

\section{Field sampling}

Sampling was carried out on board RRS 'Charles Darwin' during 2 periods: March-April 2003, a period of presumed low particulate flux ( $60 \mathrm{mg} \mathrm{m}^{-2}$ $\mathrm{d}^{-1}$, Haake et al. 1993), termed the 'inter-monsoon period' (IMP); and in September-October 2003 following high particulate flux at the end of the SW monsoon ( 125 $\mathrm{mg} \mathrm{m}^{-2} \mathrm{~d}^{-1}$, Haake et al. 1993), termed the 'late monsoon period' (LMP). Sampling was conducted at the sea floor every $50 \mathrm{~m}$ water depth from 700 to $1100 \mathrm{~m}$ (Fig. 1B). These sites were defined by their depth, bottom-water oxygen concentrations and biogeochemical properties (see Tables 1 \& 2). Bottom-water oxygen data were obtained from 22 CTD casts in total deployed during the IMP and LMP between bottom-water depths of 100 to $1850 \mathrm{~m}$. The CTD was deployed as close to the seafloor as was possible ( $5 \mathrm{~m}$ above bottom). The CTD (Seabird 911) was fitted with an SBE 43 dissolved oxygen polarographic probe (Brand \& Griffiths 2009) and was calibrated using micro-Winkler titration (Hansen 1999). The micro-Winkler titration returned a correlation coefficient of 0.997 for 33 water samples measured during 'Charles Darwin' 
Cruise 145 (CD145). This calibration was used on CD146, CD150 and CD151 because oxygen concentrations within the $\mathrm{OMZ}$ were very low during these cruises and produced negative calculated concentrations from the micro-Winkler titration (Brand \& Griffiths 2009). Oxygen data from all casts were amalgamated and averaged in $5 \mathrm{~m}$ depth intervals to produce summary profiles for each season (Bett et al. $2004 a, b)$. Data were extracted from 50 m depth intervals from 700 to $1100 \mathrm{~m}$ for this study, as shown in Levin et al. (2009b).

Bottom-water oxygen concentrations were also obtained in situ (millimetres above the sedimentwater interface) with a microelectrode profiler (Profilur; Gundersen \& Jorgensen 1990) at water depths of 850, 950 and 1000 m. For exact details see Breuer et al. (2009). Briefly, the Profilur autonomous lander consisted of 5 polarographic oxygen microelectrodes with a built-in reference and internal cathode guard and one resistivity sensor (Unisense ${ }^{\circledR}$ ). The microelectrodes were calibrated on the ship before and after each deployment. Bottom-water oxygen concentrations were calculated from linear 2-point calibrations of the microelectrodes achieved in situ. The lander was deployed to the seafloor and allowed to settle for at least $1 \mathrm{~h}$ while continuously recording bottom-water oxygen. The second electrode value for calibration (zero) was recorded when the electrode penetrated the anoxic zone of the sediment, defined as the depth where the oxygen microelectrode signal reached zero current.

Sediments were sampled using a megacorer that contained 8 core tubes with an inner diameter of $9.6 \mathrm{~cm}$. During each sampling season 2 cores per drop of the megacorer were processed for infaunal macrofauna $(>0.3 \mathrm{~mm})$, except at $950 \mathrm{~m}$ where 7 cores were processed. During each sampling season 5 cores from $950 \mathrm{~m}$ (from the study of Hughes et al. 2009) were sectioned at intervals of 0 to 10 and 10 to $20 \mathrm{~cm}$. In addition, 2 cores from each depth (700 to $1100 \mathrm{~m}$, from the study of Levin et al. 2009b) were sectioned at intervals of 0 to 1,1 to 2,2 to 5 and 5 to $10 \mathrm{~cm}$, in order to study the vertical distribution of Linopherus sp. nov. All cores were preserved in $8 \%$ buffered formalin. Organisms were sieved on a $0.3 \mathrm{~mm}$ screen and sorted at $12 \times$ magnification. Linopherus sp. nov. were counted and measured (biomass and length via number of chaetigers). Morphological adaptation to hypoxia was ascertained by examining branchial structure. The branchiae are respiratory structures occurring in pairs and usually found starting on the third or fourth chaetiger (Fig. 2C shows one half of a branchial pair). The number of branchial pairs per specimen were counted. Approximate respiratory area was estimated by normalizing the number of branchial pairs of a specimen to its wet weight in milligrams.

A separate set of megacores from 800, 850, 900 and $950 \mathrm{~m}$ were sectioned at 0 to 1,1 to 2,2 to 5 and 5 to $10 \mathrm{~cm}$ and were sieved on a $0.3 \mathrm{~mm}$ screen for biochemical analyses only. From these cores, individuals of Linopherus sp. nov. and large visible filamentous bacteria were isolated from the sediment using a binocular microscope, rinsed in filtered seawater and frozen at $-20^{\circ} \mathrm{C}$; this was done when cores were retrieved on board the ship for stable isotope and lipid analyses on return to the laboratory.

Sediment samples collected for geochemical analyses $(n=1$ per depth and $n=3$ at $950 \mathrm{~m}$ during each season) were sectioned and frozen. The surface layer, i.e. 0 to $0.5 \mathrm{~cm}$ of each core, was analyzed for the following: grain size and total phytopigments as described in Levin et al. (2009b); organic carbon content $\left(\% \mathrm{C}_{\text {org }}\right)$, total nitrogen ( $\left.\% \mathrm{TN}\right)$ and stable carbon $\left(\delta^{13} \mathrm{C}\right)$ and nitrogen isotopes $\left(\delta^{15} \mathrm{~N}\right)$, as described in Cowie et al. (2009); and lipids (from $950 \mathrm{~m}$ ) as described in Jeffreys et al. (2009a). Separate megacore tubes were sampled for burrow morphology using X-radiography as described in Levin et al. (2009b). The CTD was equipped with a 24 bottle (10 1) GOFLO Rosette sampler, which was used to collect particulate organic matter (POM) from water samples (see Jeffreys et al. 2009b).

\section{Natural abundance stable isotope analysis}

Vapour phase digestion was used to remove carbonate from POM and sediment samples. Animal tissues were acidified with $1 \mathrm{M} \mathrm{HCl}$ prior to analysis. Linopherus sp. nov. and filamentous bacteria from the IMP were analyzed using a Finnigan Delta-S isotope ratio mass spectrometer (University of Boston); Linopherus sp. nov. and filamentous bacteria from the LMP were analyzed using a Europa Hydra 20/20 isotope ratio mass spectrometer (University of California Davis); $\delta^{15} \mathrm{~N}$ of sediments were analyzed using a Europa ANCA-NT 20/20 isotope ratio mass spectrometer (Scottish Crop Research Institute, Dundee); $\delta^{13} \mathrm{C}$ of POM and sediments were analyzed using a VG Prism III isotope ratio mass spectrometer (University of Edinburgh). Stable isotope ratios were expressed as $(\delta X)(\%)=\left(\mathrm{R}_{\text {sample }} / \mathrm{R}_{\text {standard }}-1\right) \times 1000$, where $X$ was either ${ }^{13} \mathrm{C}$ or ${ }^{15} \mathrm{~N}$, and $\mathrm{R}$ was either $\left({ }^{13} \mathrm{C}:{ }^{12} \mathrm{C}\right)$ or $\left({ }^{15} \mathrm{~N}:{ }^{14} \mathrm{~N}\right)$, respectively. The reference standards for carbon and nitrogen were Pee Dee 

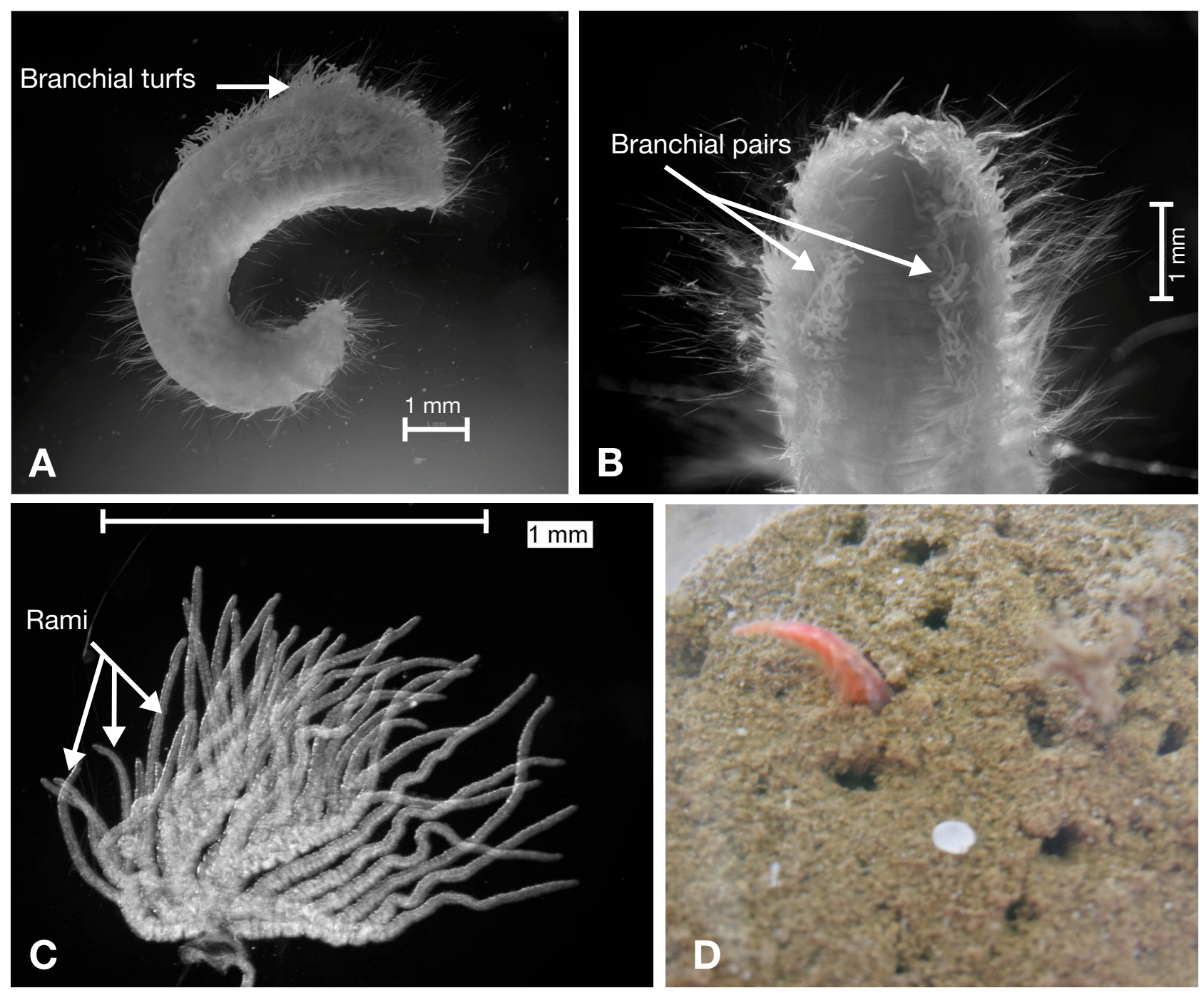

Fig. 2. Linopherus sp. nov. (A) Image of a whole specimen. (B) Dorsal view depicting branchial pairs. (C) Close-up view of a single branchia depicting branchial rami. (D) Linopherus sp. nov. exiting a burrow in a megacore; note the numerous burrow holes

Belemnite and atmospheric $\mathrm{N}_{2}$, respectively. Analytical precision was determined using an internal standard (holothurian tissue: Oneirophanta mutabilis, Iken et al. 2001), which was sent to each lab: SD values were $\pm 0.16 \%$ for $\delta^{13} \mathrm{C}$ and $\pm 0.17 \%$ for $\delta^{15} \mathrm{~N}$.

\section{Lipid analysis}

To evaluate Linopherus sp. nov. diet, lipid extractions were carried out on lypholized animal tissue ( $\mathrm{n}=3$ from each depth) from the LMP, depth range 800 to $950 \mathrm{~m}$, and are described in full in Jeffreys et al. (2009b). Briefly, separate aliquots of tissue were spiked with an internal quantification standard
$(5 \beta[\mathrm{H}]$-cholanic acid) and the total lipid extract was obtained through sonication for $60 \mathrm{~min}$ in a solvent mix of dichloromethane and methanol (9:1). Aliquots of lipids were transesterified in methanol containing acetyl chloride at $40^{\circ} \mathrm{C}$ for $12 \mathrm{~h}$ to generate fatty acid methyl esters (Christie 1982). The methylated extract was silylated using bis-trimethylsilyltrifluoroacetamide (BSFTA, $1 \%$ trimethylsilyl $; 50 \mu l_{i} 60^{\circ} \mathrm{C}_{i} 1 \mathrm{~h}$ ) to produce sterol trimethylsilyl ethers (Kiriakoulakis et al. 2001) and was spiked with an internal recovery standard $(5 \alpha[\mathrm{H}]$-cholestane). Lipid extracts were dissolved in dichloromethane and analyzed using a Trace 2000 Series gas chromatograph (on-column injector; fused high temperature silica column, $60 \mathrm{~m}$ $\times 0.25 \mathrm{~mm}$ inside diameter; $5 \%$ phenyl $/ 95 \%$ methyl 
polysiloxane equivalent phase; DB5-HT; J\&W) coupled with a Thermoquest Finnigan TSQ7000 mass spectrometer. For full operating conditions see Jeffreys et al. (2009b). Xcalibur software (v. 1.0) was used to acquire and process the data. Relative response factors (RRF) were calculated for 36 alkanoic acids, alkanols, sterols and alkenones, and from these RRFs concentrations of individual compounds were determined in samples by comparison of their peak areas with those of the internal standards (Kiriakoulakis et al. 2004). Lipid concentrations were normalized to total dry tissue weight of Linopherus sp. nov.

\section{Pulse-chase experiments}

To study the role of Linopherus sp. nov. in carbon processing, pulse-chase tracer experiments with ${ }^{13} \mathrm{C}$ labeled diatoms were carried out on intact sediments from 850 and $950 \mathrm{~m}$ with whole benthic communities present. Two approaches were used: shipboard incubations of recovered sediment cores at ambient bottom-water temperature and $\mathrm{O}_{2}$ (a $2 \mathrm{~d}$ experiment at $850 \mathrm{~m}$ during the IMP, and a $5 \mathrm{~d}$ experiment at $950 \mathrm{~m}$ during both IMP and LMP), and an in situ incubation ( $2 \mathrm{~d}$ experiment at $950 \mathrm{~m}$ during the LMP) using the benthic chamber lander 'Elinor' (Black et al. 2001). For a detailed description of the methods see Woulds et al. (2007). Briefly, shipboard experiments were carried out in the dark using duplicate megacores in a controlled temperature laboratory. Tracer experiments were initiated by introducing a slurry of $~ 80 \%$ ${ }^{13} \mathrm{C}$-labeled diatoms onto the sediment surface, to a dose of 650 to $1000 \mathrm{mg} \mathrm{C} \mathrm{m}^{-2}$ (290 $\mathrm{mg} \mathrm{C} \mathrm{m}^{-2}$ for the in situ experiment). During incubations, core top water was stirred and DO concentrations were maintained through the use of 'oxystat' gills. At the end of the experiment, megacores were sectioned as above. Linopherus sp. nov. were collected and prepared for isotope studies as described for natural abundance isotope studies. The in situ benthic lander experiments are described in detail in Woulds et al. (2007). A miniature camera system was fitted inside the lander frame to provide diagnostic information related to the experiments. The box-core recovered at the end of the in situ experiments was sub-sampled with 2 megacorer tubes, and Linopherus sp. nov. was collected and prepared for analysis as described above. Samples from ${ }^{13} \mathrm{C}$ pulse-chase experiments were analyzed for ${ }^{13} \mathrm{C}$ using a Europa Scientific tracermass isotope ratio mass spectrometer (IRMS; Crew) with a Roboprep Dumas combustion sample con- verter. Carbon contents were determined from IRMS peak areas and calibrated against standards of acetanilide, which were tailored to suit very low C samples. Linearity curves typically had $\mathrm{r}^{2}$ values greater than 0.99 and $\delta^{13} \mathrm{C}$ had an average $\mathrm{SD}$ of $0.7 \%$ o $(\mathrm{n}=27)$.

\section{Statistical analyses}

Enhanced spatial sampling resolution was carried out during this study at the expense of replication. This resulted in limited statistical analyses for some parameters owing to the absence or low number of replicate samples at each depth and time period. Initially we tested for temporal differences in the density (ind. $\mathrm{m}^{-2}$ ), biomass (wet weight, ind. $\mathrm{mg}^{-1}$ ), number of chaetigers (body length) and respiratory area (no. branchial pairs $\mathrm{mg}^{-1}$ ) of Linopherus sp. nov. at 850 and $950 \mathrm{~m}$. We were unable to make temporal comparisons at other sites owing to small sample numbers. If no significant temporal variation was noted at 850 and $950 \mathrm{~m}$, data from both seasons were then pooled in order to make comparisons of density, biomass and body length between sampling depths (i.e. 700, 850, 900, 950 and $1000 \mathrm{~m}$ for density, and 800, 850, 900 and $950 \mathrm{~m}$ for biomass and body length). Spatial differences in respiratory area were tested for in each season separately. Comparisons of Linopherus sp. nov. distribution and biomass within the sediment column were also made where possible. The distribution and variance of the data were ascertained using the Shapiro-Wilks test and Levene's homogeneity of variance test. If data had normal distribution and equal variance, a 1-way ANOVA was performed to ascertain statistical differences. If the data did not meet the assumptions of an ANOVA, a Kruskal-Wallis test or Mann-Whitney $U$-test was carried out. Relationships between environmental parameters $\left(\mathrm{O}_{2}, \% \mathrm{C}_{\text {org }} \% \mathrm{TN}\right.$, total phytopigments and grain size) and biological variables (density, biomass and respiratory area) were examined using Spearman's rank correlation.

We tested for differences in the trophic ecology of Linopherus sp. nov. using the stable isotope and lipid data. Comparisons of isotopic data across water depth zones (LMP only) and between seasons (950 m only) were analyzed using 1-way ANOVA and Mann-Whitney $U$-tests, respectively. Lipid profiles of Linopherus sp. nov. (the proportion of each compound relative to total lipid) were compared between depths on log-transformed Euclidean distance similarity matrices using non-metric multidimensional 
Table 1. Bottom water oxygen concentrations and sediment organic chemistry (surficial layer, 0 to $0.5 \mathrm{~cm}$ ) for the Pakistan margin lower oxygen minimum zone. IMP: inter-monsoon period; LMP: late monsoon period; C:N: C:N molar ratio; Total phytopigments: sum of chlorophyll and pheopigments (obtained by bulk fluorescence HPLC); nd: not determined

\begin{tabular}{|c|c|c|c|c|c|c|c|c|c|c|c|c|}
\hline \multirow{2}{*}{$\begin{array}{l}\text { Depth } \\
\text { (m) }\end{array}$} & \multicolumn{2}{|c|}{$\mathrm{CTD} \mathrm{O}_{2}(\mu \mathrm{M})$} & \multicolumn{2}{|c|}{ In situ $\mathrm{O}_{2}(\mu \mathrm{M})$} & \multicolumn{2}{|c|}{$\% \mathrm{C}_{\text {org }}$} & \multicolumn{2}{|c|}{$\% \mathrm{TN}$} & \multicolumn{2}{|c|}{$\mathrm{C}: \mathrm{N}$} & \multirow{2}{*}{$\begin{array}{c}\text { Total phyto- } \\
\text { pigments }\left(\mathrm{mg} \mathrm{g}^{-1}\right) \\
\text { IMP }\end{array}$} & \multirow{2}{*}{$\begin{array}{l}\% \\
\text { Clay } \\
\text { IMP }\end{array}$} \\
\hline & IMP & LMP & IMP & LMP & IMP & LMP & IMP & LMP & IMP & LMP & & \\
\hline 700 & 5.22 & 5.94 & nd & nd & 2.64 & 2.46 & 0.31 & 0.38 & 9.93 & 9.36 & 1.63 & 32.05 \\
\hline 750 & 5.31 & 6.02 & nd & nd & 2.74 & nd & 0.35 & nd & 9.2 & nd & nd & 34.92 \\
\hline 800 & 5.44 & 6.11 & nd & nd & 3.14 & 2.78 & 0.39 & 0.35 & 9.42 & 9.37 & 2.09 & 35.37 \\
\hline 850 & 5.58 & 6.25 & nd & $<0.01$ & 3.11 & 3.14 & 0.38 & 0.36 & 9.45 & 9.56 & 1.05 & 30.51 \\
\hline 900 & 5.71 & 6.56 & nd & nd & 3.51 & 3.49 & 0.44 & 0.44 & 9.37 & 9.16 & 0.72 & 33.26 \\
\hline 950 & 5.94 & 6.78 & $1.7 \pm 0.5$ & $2.8 \pm 0.7$ & 3.53 & 3.61 & 0.42 & 0.44 & 9.70 & 9.70 & nd & nd \\
\hline 1000 & 6.52 & 7.76 & nd & $9.3 \pm 3.7$ & 2.69 & 3.14 & 0.33 & 0.38 & 9.47 & 9.53 & 1.39 & 32.58 \\
\hline 1050 & 7.32 & 8.88 & nd & nd & 3.10 & $\begin{array}{l}3.16 \\
3.16\end{array}$ & 0.38 & 0.40 & 9.41 & 9.20 & 1.52 & 29.44 \\
\hline 1100 & nd & nd & nd & nd & 3.17 & 3.14 & 0.38 & 0.39 & 9.80 & 9.38 & 2.17 & 26.64 \\
\hline
\end{tabular}

scaling. Compounds that contributed a mean of less than $0.5 \%$ to the profile were omitted from statistical analyses. Differences in the lipid profiles were ascertained using analysis of similarities (ANOSIM). The compounds responsible for these differences were determined using SIMPER analyses (Clarke \& Warwick 2001). All multivariate statistical analyses were performed using PRIMER 6 software (PRIMER-E; Clarke 1993). Within the pulse-chase experiments, the relationship between the biomass (dry weight) of an individual Linopherus sp. nov. and its uptake of labeled tracer during the experiments was examined using simple linear correlation analyses $(\alpha=0.05)$. All univariate statistical tests were carried out using SPSS Statistics 20.

\section{RESULTS}

\section{Oxygen and organic matter gradients}

Detailed descriptions of the environmental conditions at the PM can be found in Brand \& Griffiths (2009), Breuer et al. (2009), Cowie et al. (2009), Jeffreys et al. (2009a), Levin et al. (2009b) and Woulds \& Cowie (2009). Briefly, DO concentrations based on CTD casts, increased gradually from low values of $\sim 5-6 \mu \mathrm{M}$ at $700 \mathrm{~m}$ to $\sim 7-9 \mu \mathrm{M}$ at $1050 \mathrm{~m}$ (Table 1). In situ lander measurements of DO ( $\mathrm{mm}$ above the sediment-water interface) increased from $<0.01 \mu \mathrm{M}$ at $850 \mathrm{~m}$ to $9.3 \mu \mathrm{M}$ at $1000 \mathrm{~m}$. At $950 \mathrm{~m}$, in situ DO increased from $1.7 \mu \mathrm{M}$ during the IMP to $2.8 \mu \mathrm{M}$ during the LMP.

Organic carbon $\left(\% \mathrm{C}_{\text {org }}\right)$, used here as a proxy for the concentration of OM in surficial sediments $(0$ to $0.5 \mathrm{~cm}$ ), increased from $\sim 2.5 \%$ at $700 \mathrm{~m}$ to $\sim 3.6 \%$ at $950 \mathrm{~m}$ and then decreased to $\sim 3.1 \%$ at $1050 \mathrm{~m}$. Total nitrogen concentrations mirrored those of organic carbon (Table 1). C:N ratios ranged from 9.2 to 9.9 and exhibited no obvious trend with water depth. Grain size was not correlated with $\% \mathrm{C}_{\text {org }}$ and displayed no consistent trend across the lower OMZ boundary (Table 1).

Sedimentary $\delta^{13} \mathrm{C}$ and $\delta^{15} \mathrm{~N}$ values ranged from -21.1 to $-20.1 \%$ and from 6.8 to $8.0 \%$, respectively (Table 2). Stable isotopic signatures of bacteria ranged from -27.8 to $-16.0 \%$ and from -0.4 to $7.2 \%$ for $\delta^{13} \mathrm{C}$ and $\delta^{15} \mathrm{~N}$, respectively (Table 2). Isotopic signatures of food sources, including bacteria, POM and sediment were clearly differentiated (Table 2). Mean isotopic values of surficial sediments at $950 \mathrm{~m}$ displayed no significant difference between seasons. $\delta^{13} \mathrm{C}$ values of surficial sediments were isotopically lighter at shallower depths, 700 to $900 \mathrm{~m}$, compared with depths of 950 to $1100 \mathrm{~m}$ (Table 2). In contrast, $\delta^{15} \mathrm{~N}$ values of surficial sediments showed no consistent pattern with water depth across the lower OMZ (Cowie et al. 2009).

Table 2. Stable carbon and nitrogen isotopic values (\%o) of food sources at the Pakistan margin lower oxygen minimum zone. POM: particulate organic matter collected from bottom waters; nd: not determined

\begin{tabular}{|c|c|c|c|c|c|c|}
\hline \multirow{2}{*}{$\begin{array}{l}\text { Depth } \\
\text { (m) }\end{array}$} & \multicolumn{2}{|c|}{ Sediments } & \multicolumn{2}{|c|}{$-\mathrm{POM}-$} & \multicolumn{2}{|c|}{ - Bacteria } \\
\hline & $\delta^{13} \mathrm{C}$ & $\delta^{15} \mathrm{~N}$ & $\delta^{13} \mathrm{C}$ & $\delta^{15} \mathrm{~N}$ & $\delta^{13} \mathrm{C}$ & $\delta^{15} \mathrm{~N}$ \\
\hline 700 & -20.7 & 7.4 & nd & nd & nd & nd \\
\hline 750 & -20.6 & 6.8 & nd & nd & nd & nd \\
\hline 800 & -21.1 & 6.8 & nd & nd & -25.5 to -27.8 & -0.4 to 7.2 \\
\hline 850 & -20.7 & 7.3 & nd & nd & -17.6 & 1.3 \\
\hline 900 & -20.8 & 7.1 & nd & nd & nd & nd \\
\hline 950 & -20.5 & 7.9 & -23.2 & 8.4 & -16.0 & 2.0 \\
\hline 1000 & -20.4 & 7.3 & nd & nd & -25.1 & 6.5 \\
\hline 1050 & -20.5 & 7.0 & nd & nd & nd & nd \\
\hline 1100 & -20.1 & 8.0 & nd & nd & nd & nd \\
\hline
\end{tabular}






Fig. 3. Linopherus sp. nov. (A) Density, (B) length, (C) individual biomass size and (D) approximate respiratory area (BP: branchial pairs), as a function of water depth within the lower oxygen minimum zone transition zone. Error bars represent \pm 1 SD. (A) Averages for each depth (seasonal data have been pooled); $\mathrm{n}=3$ at 700,850 and $900 \mathrm{~m}, 1$ at $750 \mathrm{~m}, 2$ at 800 and $1050 \mathrm{~m}, 14$ at $950 \mathrm{~m}$ and 4 at $1000 \mathrm{~m}$. (B,C) Averages for each depth (seasonal data have been pooled) $\mathrm{n}=7,35,11$ and 157 at 800, 850, 900 and $950 \mathrm{~m}$, respectively. (D) Averages for each depth during each season. - inter-monsoon period (IMP); O: late monsoon period (LMP); $\mathrm{n}=6,22,10$ and 157 at $800,850,900$ and $950 \mathrm{~m}$, respectively, during the IMP, and $\mathrm{n}=$ 6 and 51 at 850 and $950 \mathrm{~m}$, respectively, during the LMP

Phytopigments, biomarkers for fresh OM, were more abundant at lower oxygen concentrations. Similar concentrations were observed both within the OMZ core and at the lower OMZ boundary (Woulds \& Cowie 2009). However, no obvious trend in pigment concentrations was observed within the lower OMZ transition zone (Table 1).

Lipid distributions and biomarkers in surficial sediments at $950 \mathrm{~m}$ displayed evidence of temporal variation in relation to the POM flux (Jeffreys et al. 2009a). No clear trend was observed in lipid distributions of the sediments across the PM (140 to $1850 \mathrm{~m}$ ) except at $\sim 1200 \mathrm{~m}$ (the edge of the lower OMZ boundary), where the lowest concentrations of labile lipids were detected.

\section{Linopherus sp. nov. density, biomass and body size}

The dominant species at the lower OMZ is an undescribed polychaete species within the family Amphinomidae and the genus Linopherus (Fig. 2). Linopherus sp. nov. was present from 800 to $1000 \mathrm{~m}$ and was not found in samples collected above or below these depths. Peaks in densities were observed at $850 \mathrm{~m}$, ranging from 2348 to 5664 ind. $\mathrm{m}^{-2}$ (Fig. $3 \mathrm{~A}_{1} \mathrm{O}_{2}: 5.4$ to $6.1 \mu \mathrm{M}$ ). Densities were significantly higher at $850 \mathrm{~m}$ compared with those at 900, 950 and $1000 \mathrm{~m}$ (both seasons combined, KruskalWallis test: $\mathrm{p}=0.003$ ). Linopherus sp. nov. accounted for $100 \%$ of the macrofauna at $800 \mathrm{~m}$, $\sim 84 \%$ at $850 \mathrm{~m}, \sim 44 \%$ at $900 \mathrm{~m}, \sim 18 \%$ at $950 \mathrm{~m}$ and only $2 \%$ at $1000 \mathrm{~m}$. For macrofaunal species occurring alongside Linopherus sp. nov. and community diversity metrics, see Tables S1 \& S2 in Supplement 1 at www.int-res.com/articles/suppl/m470p079_supp. pdf, which have been adapted from Levin et al. (2009b). Diversity and evenness of the macrofaunal community was lowest at depths where Linopherus sp. nov. was the dominant species, e.g. 800 and $850 \mathrm{~m}$ (Levin et al. 2009b; Table S2). A seasonal comparison of Linopherus sp. nov. density was only possible at $950 \mathrm{~m}$, where no significant difference in density was observed (Mann-Whitney $U$-test: $p=$ 0.062). Spatial distribution patterns were similar during the IMP and LMP across the lower OMZ boundary.

Individuals were found from 0 to $10 \mathrm{~cm}$ in the sediment cores; vertical distribution varied with water depth. Individuals were concentrated near the sediment-water interface at shallower depths and worms were found deeper in the sediment with increasing water depth and oxygen concentration of overlying waters. At $800 \mathrm{~m}, 100 \%$ of Linopherus sp. nov. were found in the top $1 \mathrm{~cm}$ of the sediment. At $850 \mathrm{~m}, 82$ and $18 \%$ of individuals were found in the upper $2 \mathrm{~cm}$ and at 3 to $5 \mathrm{~cm}$ of the sediment, respectively. In contrast, at $950 \mathrm{~m}, 30 \%$ of individuals were 
found in the upper $2 \mathrm{~cm}$ and $70 \%$ at 3 to $5 \mathrm{~cm}$ within the sediment.

Linopherus sp. nov. are relatively large worms for the deep sea. Specimens collected in this study had 7 to 31 chaetigers and wet weights of 0.7 to $45 \mathrm{mg}$ (Fig. 3B,C). No significant temporal variation was found in the number of chaetigers (Mann-Whitney $U$-test: $\mathrm{p}=0.282$ and $\mathrm{p}=0.611$ for 850 and $950 \mathrm{~m}$, respectively). The species appears to exhibit allometric size structuring with depth and oxygen concentration (Fig. 3B,C). Combining data from both seasons, Linopherus sp. nov. had significantly fewer chaetigers at shallower depths (800 and $850 \mathrm{~m}$ compared with 900 and 950 m, Kruskal-Wallis test: $\mathrm{p}<0.0001$; Fig. 3B). Approximately $60 \%$ of polychaetes at $850 \mathrm{~m}$ had $<15$ chaetigers compared with $\sim 30 \%$ of polychaetes at 900 and $950 \mathrm{~m}$.

The biomass of Linopherus sp. nov. did not vary temporally at either $850 \mathrm{~m}\left(F_{1,20}=1.925, \mathrm{p}=0.181\right)$ or $950 \mathrm{~m}$ (Mann-Whitney $U$-test: $\mathrm{p}=0.076$ ). Significant spatial variation in the biomass of Linopherus sp. nov. was evident; worms were lighter at shallower depths (Kruskal-Wallis test: $\mathrm{p}=0.019$; mean wet weights were $12.6 \mathrm{mg}$ at $800 \mathrm{~m}, 16.3 \mathrm{mg}$ at $850 \mathrm{~m}, 21.6 \mathrm{mg}$ at

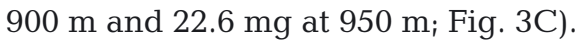

Larger worms (based on the number of chaetigers) were found deeper within the sediment (below $2 \mathrm{~cm}$ ), at the shallower sites (seasonal data and 800 and 850 m combined, Kruskal-Wallis test: $p=0.052$ ). The mean number of chaetigers was 16.6 for worms at $1.5 \mathrm{~cm}$ and 22.0 at $3.5 \mathrm{~cm}$ within the sediment column. No significant trend in Linopherus sp. nov. biomass was observed downcore $\left(F_{2,25}=1.059, \mathrm{p}=0.362\right.$ for 800 and $850 \mathrm{~m}$ combined and $F_{3,58}=1.975, \mathrm{p}=$ 0.128 for 900 and $950 \mathrm{~m}$ combined).

\section{Branchial morphology}

Linopherus sp. nov. possesses numerous dendritic branchial tufts starting at chaetiger 3 or 4 (Fig. 2A,B). Each branchia has multiple rami on its dorsal surface (Fig. 2C). The number of branchial pairs ranged from 3 to 14. Approximate respiratory area (the number of branchial pairs [BP] normalized to wet weight in milligrams, BP $\mathrm{mg}^{-1}$ ) was estimated for each individual and ranged from 0.24 to $7.14 \mathrm{BP} \mathrm{mg}^{-1}$ (Fig. 3D).

No temporal variation in approximate respiratory area was observed in worms at $850 \mathrm{~m}$ (Mann-Whitney $U$-test: $\mathrm{p}=0.121)$. At $950 \mathrm{~m}$, approximate respiratory area was significantly higher during the IMP at

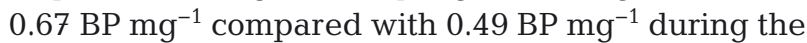
LMP (Mann-Whitney $U$-test: $\mathrm{p}=0.003$ ). During the
IMP, approximate respiratory area was highest at $850 \mathrm{~m}$ followed by 800, 900 and $950 \mathrm{~m}$ (KruskalWallis test: $p=0.017$; Fig. 3D). There was no significant difference in approximate respiratory area between 850 and $950 \mathrm{~m}$ during the LMP (MannWhitney $U$-test: $\mathrm{p}=0.327$ ). Approximate respiratory area did not vary with living depth in the sediment (Kruskal-Wallis test: $\mathrm{p}>0.1$ at both 850 and $950 \mathrm{~m}$ during both seasons).

\section{Bioturbation and lifestyle}

Linopherus sp. nov. constructs distinctive, semipermanent burrows (Fig. 4). Burrows were rare $(<30$ burrows $10 \mathrm{~cm}^{-2}$ ) but visible from 700 to $800 \mathrm{~m}$, where uniform, unbroken laminations were the dominant sedimentary feature. Burrow counts increased from $\sim 110$ burrows $10 \mathrm{~cm}^{-2}$ at $800 \mathrm{~m}$ to $\sim 162$ burrows $10 \mathrm{~cm}^{-2}$ at $850 \mathrm{~m}$, where densities of Linopherus sp. nov. were highest. At these depths sediments were criss-crossed by a network of burrows up to $1 \mathrm{~cm}$ long and 0.5 to $2 \mathrm{~mm}$ wide, and sediments were bioturbated to a depth of $\sim 8 \mathrm{~cm}$ (Fig. 4). However, laminations were still visible, suggesting that bioturbation is limited to movement of materials in and out of burrows. Between depths of 700 and $1050 \mathrm{~m}$, burrow counts and the density of Linopherus sp. nov. were positively correlated (Spearman's rank correlation coefficient $\left[\mathrm{r}_{\mathrm{S}}\right]=0.812, \mathrm{p}=0.05$; Levin et al. 2009b). While it is not possible to be sure that all burrows visible in X-radiographs can be ascribed to Linopherus sp. nov., it is likely that most large visible burrows between 800 and $1000 \mathrm{~m}$ water depth were made by this species.

Behavioural observations of Linopherus sp. nov. were made from black and white video recordings from benthic chamber lander in situ deployments at 850 m (see Video Recording V1 in Supplement 2 at www.int-res.com/articles/suppl/m470p079_supp/). The video recordings reveal an interface-dwelling mode, with amphinomid worms positioned half in and half out of the sediment and moving from side to side. The amphinomid worms seen moving within the water column in the video recordings may have been disturbed by the magnetic stirrer used to mix the chamber water during the experiment.

\section{Trophic ecology and organic matter processing}

Collectively the $\delta^{13} \mathrm{C}$ values of Linopherus sp. nov. ranged from -8.3 to $-19.2 \%$, falling within the ranges of possible food sources, i.e. sediments and 

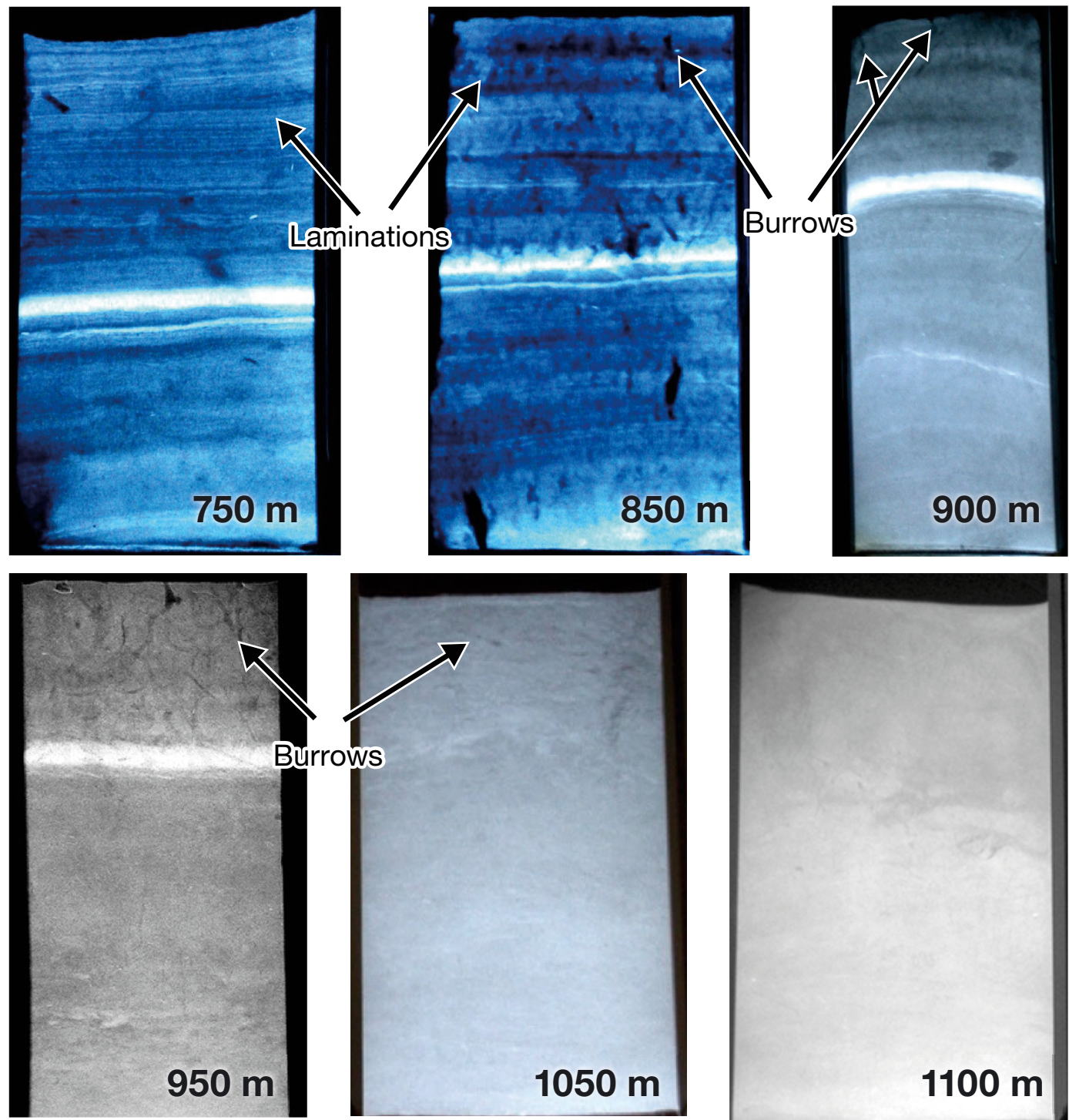

Fig. 4. X-radiographs of Pakistan margin sediments (as shown in Levin et al. 2009b) taken in May 2003, except at 950 m, which is from October 2003. All of the slabs shown measure $6.9 \times 0.9 \times 14.5 \mathrm{~cm}$, except that from $900 \mathrm{~m}$, which measures $8 \times 1.2 \times 24 \mathrm{~cm}$

bacteria (Fig. 5A). Values for $\delta^{15} \mathrm{~N}$ ranged from 9.7 to $14.5 \%$ and were enriched by 2.0 to $7.6 \%$ compared with surficial sediments and bacteria (Fig. 5A). Depth-integrated stable isotopic signatures of Linopherus sp. nov. were not significantly different both across the lower OMZ and within the sediment. Nitrogen isotopic values of Linopherus sp. nov. at $950 \mathrm{~m}$ were significantly depleted in ${ }^{15} \mathrm{~N}$ during the IMP in comparison with the LMP (11.3 and $13.4 \%$ for the IMP and LMP, respectively; Mann-Whitney $U$ test: $p=0.007)$. Allometric differences in stable isotopic compositions were also detected, with smaller individuals having more depleted $\delta^{15} \mathrm{~N}$ signatures (up to $2 \%$ ) compared with larger worms (Fig. 5B).
Lipid contents of Linopherus sp. nov. ranged from $\sim 159$ to $2578 \mu \mathrm{g} \mathrm{g}^{-1}$ relative to dry tissue weight and generally increased with increasing water depth. Both sterols and fatty acids (FAs) were dominant in terms of lipid class (Fig. 6A,B). Saturated FAs (SFAs) ranged from $\mathrm{C}_{14}$ to $\mathrm{C}_{24}$, the dominant homologues being $\mathrm{C}_{16}$ and $\mathrm{C}_{18}$. Branched FAs were minor constituents of the total lipids $(<2 \%)$ and were represented by both iso- and anteiso-FAs, ranging from $\mathrm{C}_{15}$ to $\mathrm{C}_{19}$. Monounsaturated FAs (MUFAs) ranged from $\mathrm{C}_{16: 1}$ to $\mathrm{C}_{24: 1}$ with $\mathrm{C}_{16: 1(\mathrm{n}-9)}, \mathrm{C}_{18: 1(\mathrm{n}-9)}$ and $\mathrm{C}_{20: 1(\mathrm{n}-11)}$ being the dominant homologues. Polyunsaturated FAs (PUFAs) ranged from $\mathrm{C}_{18: 2}$ to $\mathrm{C}_{23: 2}$, and distributions were dominated by $\mathrm{C}_{20: 4(\mathrm{n}-6)}, \mathrm{C}_{20: 5(\mathrm{n}-3)}$ and 
Linopherus sp. 950 m IMP $\square$ Linopherus sp. 950 m LMP $\square$ Linopherus sp. all depths
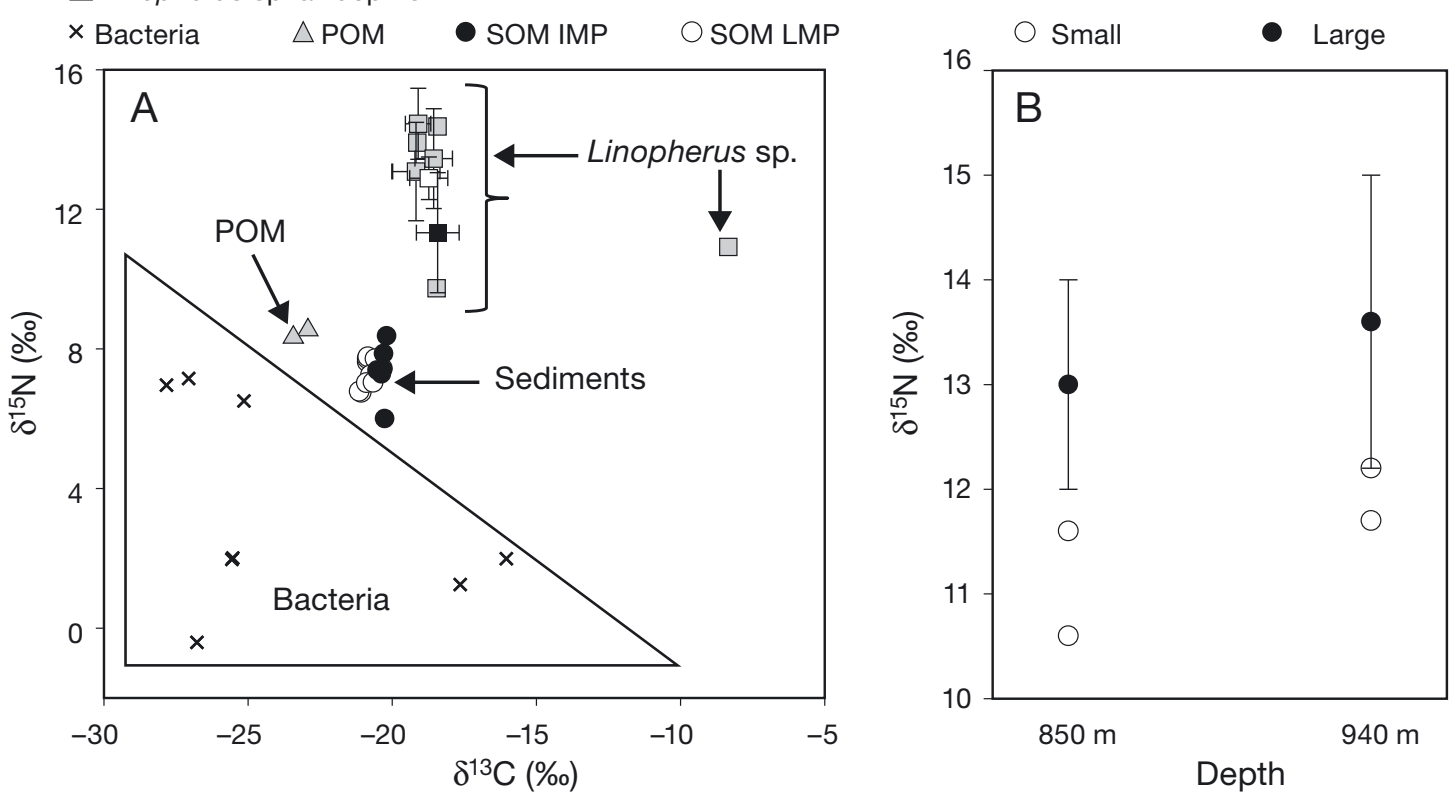

Fig. 5. (A) Dual isotope plot depicting average stable $\delta^{13} \mathrm{C}$ and $\delta^{15} \mathrm{~N}$ isotope values of Linopherus sp. nov. and its food sources. POM: particulate organic matter; SOM: sedimentary organic matter; IMP and LMP: inter- and late monsoon periods, respectively. (B) $\delta^{15} \mathrm{~N}$ isotope plot of large ( $>15$ chaetigers, $\left.\mathrm{n}=12\right)$ and small $(<15$ chaetigers, $\mathrm{n}=2)$ Linopherus sp. nov. from 850 and $950 \mathrm{~m}$ during the LMP. Error bars represent $\pm 1 \mathrm{SD}$

$\mathrm{C}_{22: 6(\mathrm{n}-3)}$. SFAs, MUFAs and PUFAs were present in roughly equal proportions (Fig. 6B). Sterol distributions were dominated by cholesterol $\left(\mathrm{C}_{27} \Delta^{5}\right)$ and ranged in carbon number from $\mathrm{C}_{26}$ to $\mathrm{C}_{29}$ i they were present in both saturated and unsaturated forms. The most abundant sterols following cholesterol were $\mathrm{C}_{27} \Delta^{5,22}$ and the brassicasterol $\left(\mathrm{C}_{28} \Delta^{5,22}\right)$. Alcohols accounted for $<2 \%$ of the total lipid and were present in both saturated and unsaturated forms, ranging from $\mathrm{C}_{14}$ to $\mathrm{C}_{20}$. The $\mathrm{C}_{16: 0}$ and $\mathrm{C}_{18: 0} \alpha$-hydroxy acids were present in worms at 900 and $950 \mathrm{~m}$ in minor amounts $(<1 \%$ total lipid $)$.

FAs and sterols of Linopherus sp. nov. displayed clustering by depth, except for $900 \mathrm{~m}$ (as shown by 3dimensional scaling, Fig. 6C,D). The effect of depth on both the sterol and FA concentrations of Linopherus sp. nov. was weak (ANOSIM: $\mathrm{R}=0.327, \mathrm{p}=$ 0.031 and $\mathrm{R}=0.361, \mathrm{p}=0.033$ for sterols and FAs, respectively). Differences in sterol distributions were found between 800 and $850 \mathrm{~m}$, and between $950 \mathrm{~m}$ and the 2 shallower depths. These differences were driven by the phytosterols $\mathrm{C}_{28} \Delta^{5,22}, \mathrm{C}_{29} \Delta^{5}$ and $\mathrm{C}_{28} \Delta^{5}$ and the invertebrate sterols $\mathrm{C}_{27} \Delta^{5}$ and $\mathrm{C}_{27} \Delta^{5,22}$, these being most abundant in worms at $950 \mathrm{~m}$ and more abundant in worms at $800 \mathrm{~m}$ compared with $850 \mathrm{~m}$ (SIMPER analysis, Table S3 in Supplement 1). Differ- ences in FA distributions were found between 800 and $850 \mathrm{~m}$ and between $950 \mathrm{~m}$ and the 2 shallower depths. Differences between 800 and $850 \mathrm{~m}$ were driven by the FAs $\mathrm{C}_{22: 6(\mathrm{n}-3)}, \mathrm{C}_{20: 5(\mathrm{n}-3)}, \mathrm{C}_{22: 5(\mathrm{n}-3)}$ and $\mathrm{C}_{16: 1(\mathrm{n}-7)}$, which were more abundant in worms at 850 m (SIMPER analysis, Table S4 in Supplement 1). Differences between $950 \mathrm{~m}$ and the 2 shallower sites were accounted for by the FAs $\mathrm{C}_{16}, \mathrm{C}_{16: 1(\mathrm{n}-7)}, \mathrm{C}_{20: 1(\mathrm{n}-9)}$, $\mathrm{C}_{20: 1(\mathrm{n}-11)}, \mathrm{C}_{18: 1(\mathrm{n}-9)}$ and $\mathrm{C}_{22: 6(\mathrm{n}-3)}$; worms at $850 \mathrm{~m}$ had higher abundances of these FAs compared with those at $950 \mathrm{~m}$. Worms at $800 \mathrm{~m}$ had higher abundances of the $\mathrm{C}_{16}$ FA compared with those at $950 \mathrm{~m}$, which in turn had higher abundances of zooplankton and invertebrate FAs, e.g. $\mathrm{C}_{20: 1}$ and $\mathrm{C}_{18: 1(\mathrm{n}-9)}$ (SIMPER analysis, Table S3).

During the ${ }^{13} \mathrm{C}$ pulse-chase experiments of Woulds et al. (2007), Linopherus sp. nov. was observed to rapidly ingest large amounts of labeled algae. This was evident in 2 ways: (1) by examination of individuals under the microscope, Linopherus sp. nov was observed with guts full of green labeled phytodetritus, and (2) through their uptake of labeled phytodetritus in the control experiments (T0), which were ended within $2 \mathrm{~h}$ of the addition of the labeled algae. In Expt T0 at $950 \mathrm{~m}$ during the LMP, the population of Linopherus sp. nov. within a single core $\left(78 \mathrm{~cm}^{2}\right)$ 



Fig. 6. Linopherus sp. nov. lipid distributions - (A) $\mu \mathrm{g} \mathrm{g}^{-1}$ tissue and (B) as a percentage relative to total lipid — as a function of depth. Compound classes are: saturated fatty acids (SFAs), branched fatty acids (BrFAs), monounsaturated fatty acids (MUFAs), polyunsaturated fatty acids (PUFAs), sterols and alcohols. Error bars represent mean $\pm 1 \mathrm{SD}, \mathrm{n}=3$. (C) 3D scaling ordination of the sterol distribution of Linopherus sp. nov. (D) 3D scaling ordination of the fatty acid distribution of Linopherus sp. nov.

ingested $\sim 5 \%(240 \mu \mathrm{g}$ of algal $\mathrm{C})$ of the added label within $2 \mathrm{~h}$. In the longer experiments ( $t=2$ to $5 \mathrm{~d})$, uptake of algal $\mathrm{C}$ by Linopherus sp. nov. ranged from 400 to $626 \mu \mathrm{g}$ and accounted for between 36 and $85 \%$ of total macrofaunal uptake. In the $5 \mathrm{~d}$ in vitro experiments at $950 \mathrm{~m}$, uptake of labeled carbon by Linopherus sp. nov. was higher during the IMP compared with the LMP (64 and $36 \%$ of total macrofauna uptake during the IMP and LMP, respectively). The proportion of label taken up by Linopherus sp. nov. during the $2 \mathrm{~d}$ in vitro experiment at $850 \mathrm{~m}$ and the $5 \mathrm{~d}$ in situ experiment at $950 \mathrm{~m}$ was similar at $85 \%$ of the total macrofaunal uptake (Fig. 7A). In the shipboard experiments (at 850 and $950 \mathrm{~m}$ and during both seasons), Linopherus sp. nov. found deeper in the sediment (at 2 to $3 \mathrm{~cm}$ ) ingested more labeled algae than those found at the surface. Conversely, during the in situ experiment at $950 \mathrm{~m}$, Linopherus sp. nov. found at the surface ingested greater amounts of label than those found deeper in the sediment (Fig. 7B). Positive correlations were observed at $950 \mathrm{~m}$ between Linopherus sp. nov. biomass (dry weight) and Linopherus sp. nov. uptake of label during both the IMP and LMP (Table 3). No correlation was apparent in the experiments at $850 \mathrm{~m}$.

Total resource use of ${ }^{13} \mathrm{C}$-labeled algae by macrofauna across the PM was low at 140, 1200 and $1850 \mathrm{~m}$ (Table 4). This coincides with the high species diversity at 140 and $1850 \mathrm{~m}$ (Table 4). At sites where Linopherus sp. nov. was dominant and species diversity was low (i.e. 850 and $950 \mathrm{~m}$ ), total resource use was high (Table 4). 

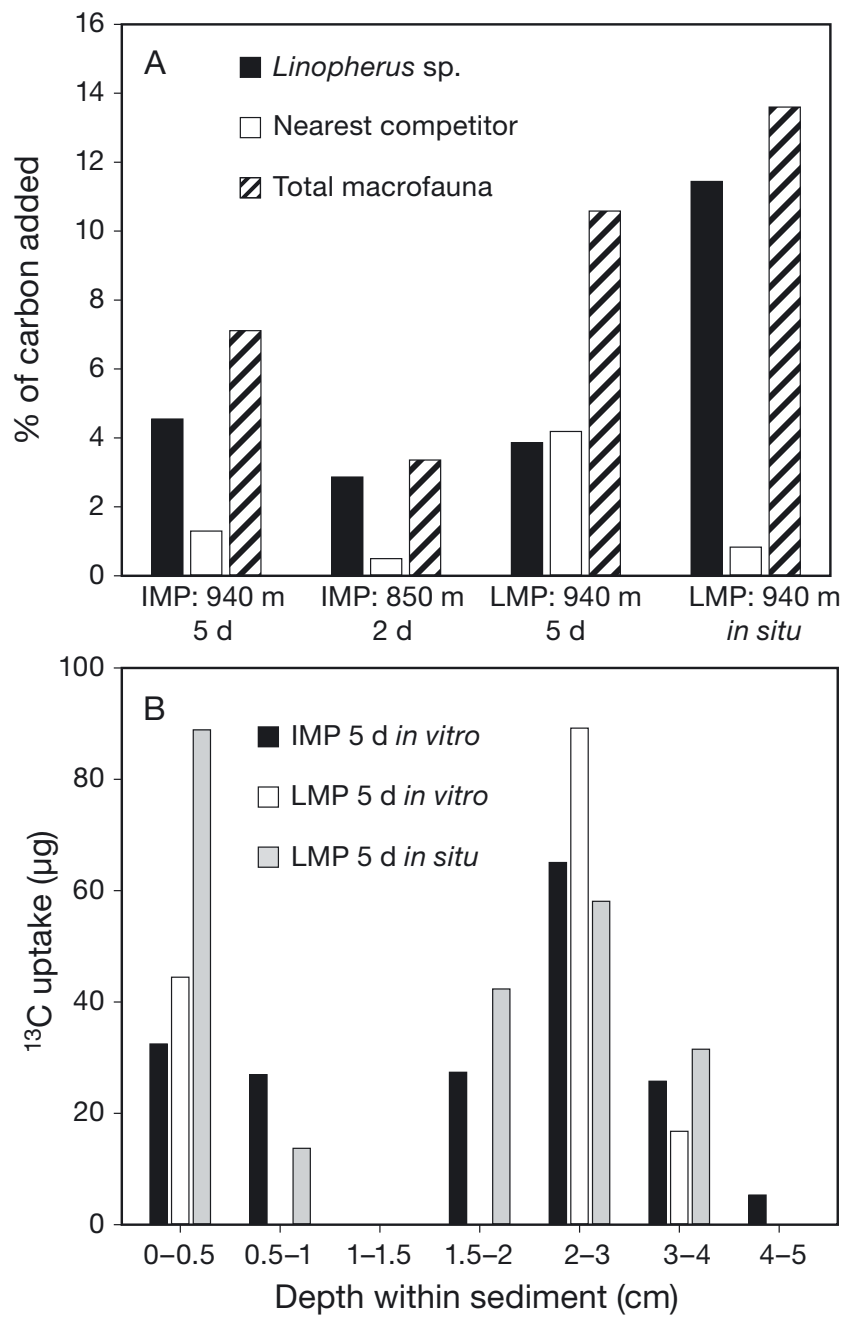

Fig. 7. Linopherus sp. nov. (A) Percentage of added C recovered from Linopherus sp. nov. in the ${ }^{13} \mathrm{C}$ pulse-chase experiments (shipboard and in situ) compared with that recovered from its nearest competitor in each case, and from the total metazoan macrofaunal population. $2 \mathrm{~d}$ and $5 \mathrm{~d}$ indicate the duration of shipboard experiments. (B) Uptake of ${ }^{13} \mathrm{C}$ by Linopherus sp. nov. across different sediment horizons from pulse-chase experiments at $950 \mathrm{~m}$. In vitro experiments are shipboard incubations. Adapted from Woulds et al. (2007).

IMP: inter-monsoon period; LMP: late monsoon period

\section{Interaction with oxygen and organic matter}

The density of Linopherus sp. nov. across the lower OMZ boundary was not correlated with any of the measured environmental parameters (Table 5). Individual biomass of Linopherus sp. nov. was correlated with both oxygen and organic carbon across the lower OMZ boundary $\left(\mathrm{r}_{\mathrm{S}}=1.0, \mathrm{p}<0.01\right.$ for both oxygen and organic carbon; Table 5). During the IMP, respiratory area of Linopherus sp. nov. was significantly negatively correlated with oxygen across the lower OMZ boundary $\left(\mathrm{r}_{\mathrm{S}}=-0.250, \mathrm{p}=0.05\right.$; Table 5). At $950 \mathrm{~m}$ the decrease in respiratory area of Linopherus sp. nov. from the IMP to the LMP was negatively correlated with oxygen concentration $\left(\mathrm{r}_{\mathrm{S}}=\right.$ $-0.249, \mathrm{p}=0.03)$.

\section{DISCUSSION}

\section{Oxygen thresholds and controls on the population structure of Linopherus sp. nov.}

DO appears to exert threshold effects on the distribution of Linopherus sp. nov. across the PM, confining this species to the lower OMZ boundary. Based on the in situ Profilur lander deployments, we suggest that Linopherus sp. nov. has a lower oxygen threshold of $\leq 1 \mu \mathrm{M}$ (Tables $1 \& 2$ ). We suggest that Linopherus sp. nov. was not present at depths of 700 and $750 \mathrm{~m}$ as oxygen concentrations fell below the lower oxygen threshold of this polychaete. Although there were no in situ DO measurements at 700 and $750 \mathrm{~m}$ to support this, we base our suggestion on the observations of Breuer et al. (2009), who reported no oxygen at $300 \mathrm{~m}$, and on the lander observations at $850 \mathrm{~m}$ (present study), in which oxygen fell below the limits of detection $(0.01 \mu \mathrm{M})$.

Linopherus sp. nov. was not present at depths below $1000 \mathrm{~m}$ where in situ oxygen concentrations were

Table 3. Correlations $\left(\mathrm{r}^{2}\right)$ with $\mathrm{p}$-values between ${ }^{13} \mathrm{C}$ uptake and individual biomass of Linopherus sp. nov. during pulsechase experiments. Italics denote a Spearman's rank correlation. Significant $(p<0.05)$ results are marked with an asterisk. IMP: inter-monsoon period; LMP: late monsoon period

\begin{tabular}{|c|c|c|c|c|c|c|c|c|}
\hline \multirow[t]{3}{*}{ Parameter } & \multicolumn{4}{|c|}{ IMP } & \multicolumn{4}{|c|}{ LMP } \\
\hline & \multicolumn{2}{|c|}{$850 \mathrm{~m}$, shipboard } & \multicolumn{2}{|c|}{$950 \mathrm{~m}$, shipboard } & \multicolumn{2}{|c|}{$950 \mathrm{~m}$, shipboard } & \multicolumn{2}{|c|}{$950 \mathrm{~m}$, in situ } \\
\hline & $\mathrm{r}^{2}$ & $\mathrm{p}$ & $\mathrm{r}^{2}$ & $\mathrm{p}$ & $\mathrm{r}^{2}$ & $\mathrm{p}$ & $\mathrm{r}^{2}$ & $\mathrm{p}$ \\
\hline Weight (mg) & 3.87 & 2.69 & 2.08 & 1.33 & 4.20 & 1.39 & 4.74 & 1.99 \\
\hline${ }^{13} \mathrm{C}$ uptake $(\mu \mathrm{g})$ & 1.34 & 0.19 & 15.32 & 10.25 & 20.24 & 9.25 & 16.85 & 6.90 \\
\hline Correlation & 0.52 & 0.15 & 0.73 & $0.04^{*}$ & 0.88 & $0.0022^{*}$ & 0.72 & $0.0055^{*}$ \\
\hline $\mathrm{n}$ & \multicolumn{2}{|c|}{9} & \multicolumn{2}{|c|}{8} & \multicolumn{2}{|c|}{6} & \multicolumn{2}{|c|}{13} \\
\hline
\end{tabular}


Table 4. Mean $( \pm \mathrm{SD})$ percentage ${ }^{13} \mathrm{C}$ uptake by the macrofaunal community from $2 \mathrm{~d}$ pulse-chase experiments. Values in bold are the proportion (\%) of macrofaunal uptake accounted for by Linopherus sp. nov. Data are taken from Woulds et al. (2007). Total number of macrofaunal species (S) and total macrofauna biomass (ww: wet weight) are taken from Hughes et al. (2009) and Levin et al. (2009b). Values in bold represent the total biomass of Linopherus sp. nov. IMP: inter-monsoon period; LMP: late monsoon period; nd: not determined

\begin{tabular}{|c|c|c|c|c|c|c|}
\hline \multirow[t]{2}{*}{$\begin{array}{l}\text { Depth } \\
\text { (m) }\end{array}$} & \multicolumn{2}{|c|}{${ }^{13} \mathrm{C}$ uptake by macrofauna } & \multicolumn{2}{|c|}{$\begin{array}{c}\text { Total number of macrofaunal } \\
\text { species }(\mathrm{S})\end{array}$} & \multicolumn{2}{|c|}{$\begin{array}{l}\text { Total macrofaunal biomass } \\
\left.\text { (g ww m } \mathrm{m}^{-2}\right)\end{array}$} \\
\hline & IMP & LMP & LMP & LMP & IMP & LMP \\
\hline 140 & $17 \pm 2$ & $7 \pm 5$ & $51 \pm 5$ & $45 \pm 3$ & $6.8 \pm 3.5$ & $4.3 \pm 2.0$ \\
\hline 850 & 42 (85) & nd & 3 & 2 & $54.7(45)$ & $43.3(\mathbf{3 0 . 2})$ \\
\hline 950 & $46 \pm 2(64)$ & $47 \pm 8(\mathbf{3 6})$ & $12 \pm 1$ & $13 \pm 1$ & $66.5 \pm 4.5$ (22.7) & $25.0 \pm 19.8$ (16.8) \\
\hline 1000 & $57 \pm 2$ & nd & 4 & 12 & $52.4(\mathbf{0})$ & $91.8(\mathbf{0 . 0 6})$ \\
\hline 1200 & $1 \pm 0.5^{\mathrm{a}}$ & nd & $13 \pm 2.6$ & nd & $0.4 \pm 0.8$ & $5.3 \pm 8.3$ \\
\hline 1850 & $4 \pm 1$ & $2 \pm 1$ & $53 \pm 6$ & $44 \pm 4$ & $9.3 \pm 14.4$ & $1.6 \pm 0.8$ \\
\hline
\end{tabular}

Table 5. Spearman's rank correlations $\left(\mathrm{r}_{\mathrm{S}}\right)$ with $\mathrm{p}$-values in parentheses between environmental parameters and the density, individual biomass and respiratory area (BP: branchial pairs) of Linopherus sp. nov. Significant $(\mathrm{p}<0.05)$ results are marked with an asterisk

\begin{tabular}{|lrrr|}
\hline Parameter & $\begin{array}{c}\text { Density } \\
\left(\text { ind. } \mathrm{m}^{-2}\right)\end{array}$ & $\begin{array}{c}\text { Individual biomass } \\
(\mathrm{mg} \mathrm{ww})\end{array}$ & $\begin{array}{c}\text { Respiratory } \\
\text { area }\left(\mathrm{BP} \mathrm{mg}^{-1}\right)\end{array}$ \\
\hline $\mathrm{DO}(\mu \mathrm{M})$ & $0.146(0.729)$ & $1.000(<0.01)^{*}$ & $-0.250(0.05)^{*}$ \\
$\% \mathrm{C}_{\mathrm{org}}$ & $0.610(0.108)$ & $1.000(<0.01)^{*}$ & $-0.800(0.200)$ \\
$\% \mathrm{TN}$ & $0.610(0.115)$ & $0.738(0.262)$ & $-0.800(0.200)$ \\
Phytopigments $\left(\mathrm{mg} \mathrm{g}^{-1}\right)$ & $-0.580(0.228)$ & $0.632(0.368)$ & $0.316(0.684)$ \\
Grain size (\% Clay) & $0.111(0.812)$ & $0.400(0.600)$ & $-0.800(0.200)$ \\
\hline
\end{tabular}

demonstrated a positive allometric relationship with anaerobic metabolism (utilizing pyruvate oxidoreductase enzymes) in polychaetes inhabiting hypoxic sediments at the Chilean margin. We suggest that the large body size of Linopherus sp. nov. in the present study could be related to its capacity for anaerobic metabolism using pyruvate oxidoreductases.

Linopherus sp. nov. displayed evidence of population size structuring within the lower OMZ (Fig. 3B,C). DO and the biomass of Linopherus sp.

$\geq 9 \mu \mathrm{M}$. We suggest that Linopherus sp. nov. was outcompeted at depths of $>1000 \mathrm{~m}$ as the increase in DO at these depths coincided with oxygen thresholds of other species (Levin et al. 2009b) including megafaunal predators (Murty et al. 2009). Linopherus sp. nov. was most abundant at depths of 800 to $850 \mathrm{~m}$ (CTD $\mathrm{DO}=5.4$ to $6.25 \mu \mathrm{M}$, Profilur DO $\leq 0.01 \mu \mathrm{M}$; Fig. 3a), where its densities peaked and it dominated the macrofaunal community (Levin et al. 2009b). Surprisingly DO and population density were not significantly correlated. At the Oman and western Indian margins, at similar DO concentrations, Linopherus sp. nov. was absent and spionid or cirratulid polychaetes dominated the macrofaunal communities (Levin et al. 2000, Ingole et al. 2010, Hunter et al. 2012).

Linopherus sp. nov. is an unusually large species for the deep sea. However, similarly large polychaetes are found within the food-rich, albeit shallower, Chilean OMZ (González \& Quiñones 2000). González \& Quiñones (2000) showed that polychaetes inhabiting hypoxic/anoxic environments have more than 1 pyruvate oxidoreductase enzyme, which is utilized in anaerobic metabolism. Furthermore those authors nov. were positively correlated across the lower OMZ, where smaller individuals tolerated lower DO concentrations. Approximately $60 \%$ of Linopherus sp. nov. at $850 \mathrm{~m}$ had fewer than 15 chaetigers. These may be juveniles or reflect stunted growth. Lucicutia sp. copepods in the Arabian Sea display ontogenetic zonation across the $\mathrm{OMZ}$, where young occupy low DO waters (Wishner et al. 2000).

\section{Adaptation to low DO conditions}

Smaller-bodied organisms tend to be prevalent in OMZs as they have a greater surface area for oxygen diffusion (Levin 2003, Gooday et al. 2009). Whilst Linopherus sp. nov. are relatively large worms, morphological observations of the branchial tufts of Linopherus sp. nov. indicate that this species has greatly enlarged respiratory structures. The branchial tufts consisted of numerous branchial pairs (up to 14) with circular branching rami (Fig. 2). Similar respiratory adaptations have been observed in spionid polychaetes from the Oman margin (Lamont \& Gage 
2000), which had either numerous pairs of branchiae (up to 12) or 3 pairs of branchiae, each bearing numerous plate-like pinnules (Lamont \& Gage 2000).

Where DO was lowest on the Oman margin, larger branchial surface areas in proportion to body size were noted in spionid polychaetes (Lamont \& Gage 2000). In the present study, Linopherus sp. nov. shows a similar adaptation, having larger approximate respiratory areas concurrent with lower DO (Fig. 3D). Linopherus sp. nov. apparently enhances oxygen diffusion by increasing its body area/mass ratio, specifically at depths where DO concentrations are lowest. Furthermore, the decrease in Linopherus sp. nov. respiratory area during the LMP demonstrates that Linopherus sp. nov. may respond quickly to temporal shifts in DO.

Behavioural adaptations to low DO were also noted. In situ benthic lander observations revealed that the interface-dwelling mode of Linopherus sp. nov. involved this species moving its body from side to side. These movements may increase oxygen exposure across its branchiae.

\section{Organic matter and potential food sources at the OMZ boundary}

Relatively high $\% \mathrm{C}_{\text {org }}$ concentrations of sediments across the lower OMZ boundary (Table 1) suggest an abundance of OM/food for Linopherus sp. nov. However, C:N ratios and lipid biomarkers reflected a degraded OM source, suggesting that this material is low quality OM. Both phytopigment and lipid distributions across the PM as a whole appear to be heavily influenced by faunal feeding processes (Jeffreys et al. 2009a, Woulds \& Cowie 2009). Temporal variation in food availability is evident from lipid distributions and appears to be related to the POM flux (Jeffreys et al. 2009a).

Stable isotopic values for sediments and POM were consistent with material derived from phytoplankton and displayed evidence of water-column denitrification (Fig. 5A; Fry \& Sherr 1984, Gaye-Haake et al. 2005). Bacterial isotope values suggest fixation of carbon and nitrogen by oxidation of sulphide and by denitrification (Fig. 5a; Brooks et al. 1987, Robinson \& Cavanaugh 1995, Campbell et al. 2003).

\section{Interaction of Linopherus sp. nov. with organic matter}

The relatively large size of Linopherus sp. nov., especially for an OMZ species, suggests it has an abundant food supply. Food supply $\left(\% \mathrm{C}_{\text {org }}\right)$ was strongly and positively correlated with biomass across the lower OMZ. Concomitantly, at $950 \mathrm{~m}$ Linopherus sp. nov. biomass and density showed small increases temporally alongside increases in $\mathrm{C}_{\text {org }}$. These results suggest that Linopherus sp. nov. can take advantage of the monsoon-associated food supply to meet its energetic requirements for somatic growth.

OM quality and quantity is influenced by faunal activity (Smallwood et al. 1999, Ginger et al. 2001, Woulds et al. 2007). The relatively degraded food source observed at the PM compared with other OMZ margins results from greater mineral input via the Indus river, heterotrophic reworking of OM in the upper water column and selective feeding and uptake of OM by the benthic fauna (Jeffreys et al. 2009a, Levin et al. 2009b).

Visual evidence from X-radiographs suggests that Linopherus sp. nov. does not greatly impact sediment OM processing via bioturbation, as intact laminations are visible at sites where Linopherus sp. nov. is present (Fig. 4). However, pulse-chase experiments reveal that Linopherus sp. nov. is able to rapidly $(<2 \mathrm{~h})$ ingest/remove phytodetritus from the sediment surface in a similar way to foraminifera within the OMZ core (Larkin 2006, Woulds et al. 2007) and pennatulids at the lower OMZ boundary (Jeffreys et al. 2009a). Linopherus sp. nov. dominated the uptake of labeled carbon in experiments at the lower OMZ transition zone (Fig. 7, Table 4), suggesting that this species has a significant impact on the processing and the quality and quantity of $\mathrm{OM}$ at the sediment surface at the PM.

\section{Nutritional strategies of Linopherus sp. nov.}

Video observations and X-radiographs demonstrate that Linopherus sp. nov. is not a classic infaunal deposit feeder, as sediment laminations are still present and it is seen freely moving in and out of its burrows (Fig. 4, see Video Recording V1 in Supplement 2). Instead Linopherus sp. nov. is an opportunistic feeder capable of feeding on fresh phytodetritus, as evident from the pulse-chase experiments and visual observations of gut contents. Lipid biomarkers support this, with fatty acids $\left(\mathrm{C}_{20: 5(\mathrm{n}-3)}, \mathrm{C}_{22: 6(\mathrm{n}-3)}\right)$ and sterols $\left(\mathrm{C}_{28} \Delta^{5,22}, \mathrm{C}_{29} \Delta^{5,22}\right)$ being derived from phytodetritus ( $>15 \%$ total lipids) present in its tissues. The Amphinomidae have been classified previously as predators on hard substratum and carrion feeders in sandy/muddy environments (Fauchald \& Jumars 
1979). Our observations of Linopherus sp. nov. suggest this family has a much broader diet.

The wide range in stable isotope values indicates that Linopherus sp. nov. has an omnivorous trophic strategy (Fig. 5a). Assuming a trophic fractionation of 1.0 and 3.4 for $\delta^{13} \mathrm{C}$ and $\delta^{15} \mathrm{~N}$, respectively (Post 2002, McCutchan et al. 2003), stable isotope values for Linopherus sp. nov. were 1 to 2 trophic steps removed from the sediments, suggesting both detritivorous and predatory aspects to their diet. The $C_{18: 1(n-9)}$ : $\mathrm{C}_{18: 1(\mathrm{n}-7)}$ ratio, indicative of the degree of carnivory (Graeve et al. 1997), supports this with a mean value of 3.4. Cholesterol was the dominant sterol ( $>50 \%$ of the total sterols) present in Linopherus sp. nov. and is also an indicator of carnivory (Nelson et al. 2001), although polychaetes are able to synthesize sterols de novo (Wootton \& Wright 1962, Walton \& Pennock 1972). The second most abundant sterols included both isomers of the invertebrate biomarkers $C_{27} \Delta^{5,22}$, which may be biosynthesized by Linopherus sp. nov.

The proportion of PUFAs in the tissues of Linopherus sp. nov. was similar to those reported for abyssal polychaetes in the Pacific Ocean (Drazen et al. 2008), suggesting a link to the euphotic zone production and ingestion of phytodetritus, as most marine animals cannot synthesize long-chain PUFAs de novo (Pond et al. 2002).

Long-chain MUFAs $\left(\mathrm{C}_{20: 1}\right.$ and $\left.\mathrm{C}_{22: 1}\right)$, known to be indicative of calanoid copepods (Dalsgaard et al. 2003), were present in Linopherus sp. nov. at the PM and may reflect consumption of copepod remains or faecal pellets associated with the vertical flux, rather than direct ingestion of copepods. Crustacea (i.e. amphipods) were only present from $900 \mathrm{~m}$, where DO was $>5.8 \mu \mathrm{M}$ (Levin et al. 2009b), so assimilation of these MUFAs from direct ingestion of benthic crustacea seems unlikely.

Bacteria may be another food source for Linopherus sp. nov., and large filamentous sulphur bacteria were observed at the lower OMZ transition zone and within the burrows of Linopherus sp. nov. A single specimen from $1000 \mathrm{~m}$ had an isotopically heavy $\delta^{13} \mathrm{C}$ signature (-8.3\%o, Fig. 5A), which may be indicative of ingestion of bacteria utilizing the rTCA cycle. Bacterial FAs, including $\mathrm{C}_{18: 1(\mathrm{n}-7)}$, odd-numbered saturated and branched FAs, represented $\sim 10 \%$ of the FAs in Linopherus sp. nov. tissues, suggesting a bacterial component to the diet. Visual observations and biochemical and experimental data all suggest that Linopherus sp. nov. is an indiscriminant opportunistic omnivore that takes advantage of any available food source, although phytodetritus is likely to be its most common food source.
Seasonal and allometric differences were observed in the stable isotopic nitrogen composition of Linopherus sp. nov., smaller worms being isotopically lighter in $\delta^{15} \mathrm{~N}$ than their larger counterparts at the same sites (Fig. 5B). Similar trends have been observed in shallow-water ampharetid and spionid polychaetes and ascribed to juveniles feeding on benthic diatoms, whilst adults fed on macroalgal detritus (Hentschel 1998). At $950 \mathrm{~m}$ at the PM, nitrogen isotope values of Linopherus sp. nov. became isotopically lighter during the LMP and densities increased at this site after the SW monsoon, perhaps reflecting a recruitment event.

Lipid distributions varied with depth and worm size. Worms were smaller at the shallower sites (800 and $850 \mathrm{~m}$ ) and had relatively more abundant phytodetrital biomarkers, e.g. $\mathrm{C}_{22: 6(\mathrm{n}-3)}$ and $\mathrm{C}_{16: 1(\mathrm{n}-7) \text {, than }}$ did larger worms found deeper (900 and $950 \mathrm{~m}$ ), which had greater proportions of invertebrate biomarkers, e.g. $\mathrm{C}_{20: 1(\mathrm{n}-11)}$ and $\mathrm{C}_{27} \Delta^{5}$. Ontogenetic differences in lipid composition have been noted previously for calanoid copepods (Svetlichny et al. 2006, Laakmann et al. 2009), pteropods (Boer et al. 2005), euphasiids (Kattner \& Hagen 1998) and an alvinocaridid shrimp (Stevens et al. 2008). In the Arctic, calanoid copepods exhibit differences in trophic strategy, as inferred from lipid distributions, in order to minimize competition (Laakmann et al. 2009). In the Black Sea, vertical migrations of copepods into the OMZ have been linked to the formation of lipid reserves for reproduction (Svetlichny et al. 2000, 2006)

The strategy of Linopherus sp. nov. inferred from our data set is that smaller individuals, possibly juveniles occupying sites with the lowest DO concentrations, may (1) obtain refuge from predators, (2) minimize competition for food resources, (3) take advantage of the more abundant phytodetritus and (4) build up lipid reserves. We deduce that these smaller worms/juveniles are primarily reliant on phytodetritus whereas adults are more opportunistic and utilize scavenging as a nutritional strategy alongside feeding on phytodetritus when available.

\section{Effect of Linopherus sp. nov. on ecosystem responses to gradients in oxygen and organic matter}

Understanding ecosystem processes within OMZs is critical as hypoxia alters both the structure and function of benthic ecosystems, leading to loss of biodiversity and elevated dominance (Levin et al. 2009a). Such shifts in community structure can lead 
to changes in trophic structure, energy flow pathways, nutrient cycling, bioirrigation and OM cycling and burial (Cardinale et al. 2006, Canuel et al. 2007, Solan et al. 2008, Middelburg \& Levin 2009). The PM OMZ is particularly suited for studying the effects of biodiversity on ecosystem functioning (here defined as OM processing) as it has high faunal diversity above and below the OMZ (Hughes et al. 2009), and communities are dominated by a single species at the lower boundary (Levin et al. 2009b).

Previous studies on biodiversity and ecosystem functioning have artificially manipulated biodiversity through removal of species and have concentrated on mixtures of a few species, making extrapolations to the field difficult (Loreau et al. 2001). More recently, Karlson et al. (2010) were able to mimic field conditions in the species-poor Baltic Sea in order to understand the effect of biodiversity on OM processing, using pulse-chase experiments. Those authors concluded that ecosystems with higher species diversity (maximum number of species $=3$ ) incorporated more carbon and nitrogen, displayed more efficient trophic transfer of phytodetritus and were more productive than monocultures. The importance of single species and species-specific traits on ecosystem functioning has also been demonstrated (Solan et al. 2004, Norling et al. 2007, Godbold et al. 2009b). Hence, we now focus on Linopherus sp. nov. as a possible model for understanding small-scale ecosystem responses to gradients in OM and DO.

Linopherus sp. nov. is a low oxygen specialist (Levin et al. 2009b). As a result it is the only metazoan found at $800 \mathrm{~m}$ and dominates the macrofaunal community at $850 \mathrm{~m}$, where it occurs alongside the spionid polychaete Prionospio. Associated with this dominance are low levels of diversity (Levin et al. 2009b). As DO increases, Linopherus sp. nov. becomes less dominant and macrofaunal diversity increases; Linopherus sp. nov. is absent at DO $>7.8 \mu \mathrm{M}$ (CTD values). This DO-driven dominance has implications for the quality, quantity and processing of OM. Linopherus sp. nov. is an important consumer of OM. Pulse-chase experiments reveal that the dominance of Linopherus sp. nov. appears to increase the total resource use (i.e. ${ }^{13} \mathrm{C}$-labeled algae) by the macrofauna at the lower OMZ boundary compared with other sites at the PM (Woulds et al. 2007). For example, at 140 and $1850 \mathrm{~m}$ where macrofaunal diversity was higher, incorporation of carbon by the macrofauna was low, compared with 850 and $950 \mathrm{~m}$ where diversity was low, but incorporation of carbon was much higher (Table 4). Uptake of isotopically labeled phytodetritus was elevated at $800 \mathrm{~m}$ (com- pared with 500 and $1100 \mathrm{~m}$ ) on the Indian margin, largely due to the dominant cirratulid polychaetes (Hunter et al. 2012). Increased total resource use by a dominant species has been demonstrated previously for a wide range of environments (Cardinale et al. 2006) and specifically for coastal echinoderms (Godbold et al. 2009a). The results of Woulds et al. (2007) contradict those of Karlson et al. (2010), who found that higher metazoan macrofaunal species diversity (maximum number of species $=3$, minimum number of species $=1$ ) led to enhanced processing of phytodetritus. However, the results shown here from the PM are representative of larger multi-species communities (maximum number of species $=53$, minimum number of species $=2$ ) and demonstrate that dominant species in OMZs can have a significant impact on carbon processing.

Macrofauna can also impact OM processing by other members of the benthic community, e.g. meiofauna (Nascimento et al. 2011). At sites where Linopherus sp. nov. was dominant, foraminifera and macrofauna were less abundant and their diversity was reduced compared with other areas of the PM, notably the core of the OMZ for foraminifera (Gooday et al. 2009, Hughes et al. 2009, Levin et al. 2009b). Although the effects of depth and DO cannot be discounted, the presence of Linopherus sp. nov. has implications for the food resources available to other consumers and may affect community structure through competition for resources. Polychaetes can prey on foraminifera (Nomaki et al. 2008) and so foraminifera may also constitute an important food source for Linopherus sp. nov., thereby keeping densities low.

Levin et al. (1997) demonstrated that deep-living maldanid polychaetes can transport fresh OM to depths of $>10 \mathrm{~cm}$, thereby enabling other deep-living species to utilize this resource. Similarly, subduction of phytodetritus and/or creation of burrows into which phytodetritus may be passively deposited by Linopherus sp. nov. could enhance processing of OM through facilitating feeding by deeper-living species.

Lipid distributions of Linopherus sp. nov. suggest efficient transfer and processing of OM, reflecting its importance in OM turnover and quality. The presence of phytoplankton biomarkers, i.e. $\mathrm{C}_{22: 6(\mathrm{n}-2) \text {, }}$ $\mathrm{C}_{20: 5(\mathrm{n}-3)}$ and $\mathrm{C}_{16: 1(\mathrm{n}-7)}$, in Linopherus sp. nov. (at 800 and $850 \mathrm{~m}$ ), together with its apparent feeding behaviour (moving out of its burrows), suggests that selective feeding and uptake of lipid-rich particles occur, leaving lipid-depleted OM to be deposited at the sediment surface. Furthermore, sedimentary pigment distributions provide evidence for digestive 
alteration of OM by Linopherus sp. nov. At $950 \mathrm{~m}$ the pheophytin/pheophorbide ratio decreased with depth, suggesting that pheophorbide was produced by Linopherus sp. nov. through the digestion and breakdown of chlorophyll (Woulds \& Cowie 2009).

\section{CONCLUSIONS}

(1) DO exerts threshold effects on the distribution of the polychaete Linopherus sp. nov. This species is a low-oxygen specialist capable of tolerating in situ DO concentrations $<1 \mu \mathrm{M}$ and is not found at oxygen concentrations $\geq 12 \mu \mathrm{M}$, where it appears to become outcompeted by other macrofauna.

(2) Linopherus sp. nov. displays both ecological and morphological adaptations to low DO. Larger proportions $(\sim 60 \%)$ of smaller individuals $\quad<15$ chaetigers), possibly juveniles, are present at lower DO concentrations; these individuals have a higher surface area:volume ratio for oxygen diffusion than do large individuals. The respiratory structures of Linopherus sp. nov. are greatly enlarged, and the approximate respiratory area (normalized to body weight) is greater at lower DO. Lower DO may therefore provide a refuge from predation or cannibalism for juveniles of this species. Linopherus sp. nov. is highly mobile and either migrates to water depths with higher DO once it reaches maturity or grows to larger size at higher $\mathrm{O}_{2}$ levels.

(3) Linopherus sp. nov. are opportunistic omnivores relying on phytodetritus, bacteria and invertebrate prey for food. Pulse-chase experiments demonstrated that Linopherus sp. nov. can rapidly consume phytodetritus. The large body size of Linopherus sp. nov. may be attributed to an abundant food supply and the successful nutritional strategy of these polychaetes.

(4) Linopherus sp. nov. is proposed to influence biodiversity through: (i) its tolerance to hypoxia, thereby promoting its dominance, and (ii) competitive exclusion for resources. The presence, dominance and trophic plasticity of Linopherus sp. nov. at the lower OMZ transition zone leads to more efficient trophic transfer and processing of $\mathrm{OM}$, which has ramifications for carbon cycling on the PM.

Acknowledgements. We thank the Master, crews and science participants of the RRS 'Charles Darwin' for assistance at sea during cruises CD145, CD146, CD150 and CD151. This work was supported by Natural Environment Research Council Grant (UK) NER/A/S/2000/01381, the Leverhulme Trust (UK) and National Science Foundation (USA) Grant
INT 02-27511. P.A.L. thanks Dr. S. Kidwai for her assistance with sampling on board during CD145. We are especially grateful to Dr. E. Breuer and O. Peppe for providing the in situ oxygen data from the 850 and $1000 \mathrm{~m}$ depth sites, and to R. Michener, D. Harris and C. Scrimgeour for the isotope analyses. We also thank 3 anonymous reviewers whose constructive comments helped to improve this manuscript.
Andersson JH, Woulds C, Schwartz M, Cowie GL, Levin LA, Soetaert K, Middelburg JJ (2008) Short-term fate of phytodetritus in sediments across the Arabian Sea oxygen minimum zone. Biogeosciences 5:43-53

Bett BJ, Billet DSM, Brand T, Edwards T and others (2004a) RRS 'Charles Darwin' Cruise 145, 12 Mar-09 Apr 2003. Benthic ecology and biogeochemistry of the Pakistan Margin. In: Southampton Oceanography Centre Cruise Report, No. 50. University of Southampton, Southampton

Bett BJ, Boorman B, Kaariainen J, Jeffreys RM and others (2004b) RRS 'Charles Darwin' Cruise 150, 22 Aug15 Sep 2003. Benthic ecology and biogeochemistry of the Pakistan Margin. In: Southampton Oceanography Centre Cruise Report, No. 51. University of Southampton, Southampton

Black KS, Fones GR, Peppe OC, Kennedy HA, Bentaleb I (2001) An autonomous benthic lander: preliminary observations from the UK BENBO thematic programme. Cont Shelf Res 21:859-877

Boer M, Gannefors C, Kattner G, Graeve M, Hop H, FalkPetersen S (2005) The Arctic pteropod Clione limacina: seasonal lipid dynamics and life-strategy. Mar Biol 147: 707-717

Bopp L, Le Quéré C, Heimann M, Manning A, Monfray P (2002) Climate-induced oceanic oxygen fluxes: implications for the contemporary carbon budget. Global Biogeochem Cycles 16:1022

Brand TD, Griffiths C (2009) Seasonality in the hydrography and biogeochemistry across the Pakistan margin of the NE Arabian Sea. Deep-Sea Res II 56:283-295

Breuer ER, Law GTW, Woulds C, Cowie GL and others (2009) Sedimentary oxygen consumption and microdistribution at sites across the Arabian Sea oxygen minimum zone (Pakistan margin). Deep-Sea Res II 56: 296-304

- Brooks JM, Kennicutt MC, Fisher CR, Macko SA and others (1987) Deep sea hydrocarbon seep communities: evidence for energy and nutritional carbon sources. Science 238:1138-1142

Campbell BJ, Stein JL, Cary SC (2003) Evidence of chemolithoautotrophy in the bacterial community associated with Alvinella pompejana, a hydrothermal vent polychaete. Appl Environ Microbiol 69:5070-5078

> Canuel EA, Spivak AC, Waterson EJ, Duffy JE (2007) Biodiversity and food web structure influence short-term accumulation of sediment organic matter in an experimental seagrass system. Limnol Oceanogr 52:590-602

> Cardinale BJ, Srivastava DS, Duffy JE, Wright JP, Downing AL, Sankaran M, Jouseau C (2006) Effects of biodiversity on the functioning of trophic groups and ecosystems. Nature 443:989-992

Christie WW (1982) Lipid analysis. Permagon Press, Oxford > Clarke KR (1993) Nonparametric multivariate analyses of changes in community structure. Aust J Ecol 18:117-143 
Clarke KR, Warwick RM (2001) Change in marine communities: an approach to statistical analysis and interpretation. PRIMER-E, Plymouth

Cowie G (2005) The biogeochemistry of Arabian Sea surficial sediments: a review of recent studies. Prog Oceanogr 65:260-289

Cowie GL, Levin LA (2009) Benthic biological and biogeochemical patterns and processes across an oxygen minimum zone (Pakistan margin, NE Arabian Sea). Deep-Sea Res II 56:261-270

Cowie GL, Mowbray S, Lewis M, Matheson H, Mckenzie R (2009) Carbon and nitrogen elemental and stable isotopic compositions of surficial sediments from the Pakistan margin of the Arabian Sea. Deep-Sea Res II 56: 271-282

Criales-Hernandez MI, Schwamborn R, Graco M, Ayon P, Hirche HJ, Wolff M (2008) Zooplankton vertical distribution and migration off Central Peru in relation to the oxygen minimum layer. Helgol Mar Res 62 (Suppl 1):85-100

> Dalsgaard J, St. John M, Kattner G, Müller-Navarra D, Hagen W (2003) Fatty acid trophic markers in the pelagic marine environment. Adv Mar Biol 46:225-340

> Diaz RJ, Rosenberg R (2008) Spreading dead zones and consequences for marine ecosystems. Science 321:926-929

Diaz RJ, Rabalais NN, Levin LA (2009) The coastal dissolved oxygen squeeze: future interactions of land and ocean processes, and consequences for ecosystem services. Geochim Cosmochim Acta 73(Suppl):A289 (Abstract)

> Drazen JC, Phleger CF, Guest MA, Nichols PD (2008) Lipid, sterols and fatty acids of abyssal polychaetes, crustaceans, and a cnidarian from the northeast Pacific Ocean: food web implications. Mar Ecol Prog Ser 372: 157-167

Fauchald K, Jumars P (1979) The diet of worms: a study of polychaete feeding guilds. Oceanogr Mar Biol Annu Rev 17:193-284

Fry B, Sherr EB (1984) $\delta^{13} \mathrm{C}$ measurements as indicators of carbon flow in marine and fresh-water ecosystems. Contrib Mar Sci 27:13-47

Gallardo V, Palma M, Carrasco F, Gutiérrez D, Levin L, Canete J (2004) Macrobenthic zonation caused by the oxygen minimum zone on the shelf and slope off central Chile. Deep-Sea Res II 51:2475-2490

Gaye-Haake B, Lahajnar N, Emeis KC, Unger D and others (2005) Stable nitrogen isotopic ratios of sinking particles and sediments from the northern Indian Ocean. Mar Chem 96:243-255

> Ginger ML, Billett DSM, Mackenzie KL, Kiriakoulakis K and others (2001) Organic matter assimilation and selective feeding by holothurians in the deep sea: some observations and comments. Prog Oceanogr 50:407-421

Godbold JA, Rosenberg R, Solan M (2009a) Species-specific traits rather than resource partitioning mediate diversity effects on resource use. PLoS ONE 4:e7423

Godbold JA, Solan M, Killham K (2009b) Consumer and resource diversity effects on marine macroalgal decomposition. Oikos 118:77-86

Goes JI, Thoppil PG, Gomes HdR, Fasullo JT (2005) Warming of the Eurasian landmass is making the Arabian Sea more productive. Science 308:545-547

> González R, Quiñones R (2000) Pyruvate oxidoreductases involved in glycolytic anaerobic metabolism of polychaetes from the continental shelf off central-south Chile. Estuar Coast Shelf Sci 51:507-519

Gooday A, Bernhard J, Levin L, Suhr S (2000) Foraminifera in the Arabian Sea oxygen minimum zone and other oxygen-deficient settings: taxonomic composition, diversity, and relation to metazoan faunas. Deep-Sea Res II 47: $25-54$

Gooday AJ, Levin LA, Aranda da Silva A, Bett BJ and others (2009) Faunal responses to oxygen gradients on the Pakistan margin: a comparison of foraminiferans, macrofauna and megafauna. Deep-Sea Res II 56:488-502

Graeve M, Kattner G, Piepenburg D (1997) Lipids in Arctic benthos: Does the fatty acid and alcohol composition reflect feeding and trophic interactions? Polar Biol 18: 53-61

Gundersen JK, Jorgensen BB (1990) Microstructure of diffusive boundary layers and the oxygen uptake of the seafloor. Nature 345:604-607

Haake B, Ittekkot V, Rixen T, Ramaswamy V, Nair RR, Curry WB (1993) Seasonality and interannual variability of particle fluxes to the deep Arabian Sea. Deep-Sea Res I 40:1323-1344

Haake B, Rixen T, Reemtsma T, Ramaswamy V, Ittekkot V (1996) Processes determining seasonality and interannual variability of settling particle fluxes to the deep Arabian Sea. In: Ittekkot V, Schafer P, Honjo S, Depetris PJ (eds) Particle flux in the ocean: SCOPE 57 (SCOPE (Scientific Committee on Problems of the Environment)). John Wiley \& Sons, Chichester, p 251-268

Hansen HP (1999) Determination of oxygen. In: Grasshoff K, Kremling $K$, Ehrhardt $M$ (eds) Methods of seawater analysis. Wiley-VCH, Weinheim, p 75-89

> Helly JJ, Levin LA (2004) Global distribution of naturally occurring marine hypoxia on continental margins. DeepSea Res I 51:1159-1168

- Hentschel B (1998) Intraspecific variations in $\delta^{13} \mathrm{C}$ indicate ontogenetic diet changes in deposit-feeding polychaetes. Ecology 79:1357-1370

> Honjo S, Dymond J, Prell W, Ittekkot V (1999) Monsooncontrolled export fluxes to the interior of the Arabian Sea. Deep-Sea Res II 46:1859-1902

Hughes DJ, Lamont PA, Levin LA, Packer M, Feeley K, Gage JD (2009) Macrofaunal communities and sediment structure across the Pakistan margin Oxygen Minimum Zone, North-East Arabian Sea. Deep-Sea Res II 56:434-448

> Hunter WR, Oguri K, Kitazato H, Ansari ZA, Witte U (2011) Epi-benthic megafaunal zonation across an oxygen minimum zone at the Indian continental margin. Deep-Sea Res I 58:699-710

- Hunter WR, Levin LA, Kitazato H, Witte U (2012) Macrobenthic assemblage structure and organismal stoichiometry control faunal processing of particulate organic carbon and nitrogen in oxygen minimum zone sediments. Biogeosciences 9:993-1006

Iken K, Brey T, Wand U, Voigt J, Junghans P (2001) Food web structure of the benthic community at the Porcupine Abyssal Plain (NE Atlantic): a stable isotope analysis. Prog Oceanogr 50:383-405

> Ingole B, Sautya S, Sivadas S, Singh R, Nanajkar M (2010) Macrofaunal community structure in the western Indian continental margin including the oxygen minimum zone. Mar Ecol 31:148-166

> Jeffreys RM, Wolff GA, Cowie GL (2009a) Influence of oxygen on heterotrophic reworking of sedimentary lipids at the Pakistan Margin. Deep-Sea Res II 56:358-375

Jeffreys RM, Wolff GA, Murty SJ (2009b) The trophic ecology of key megafaunal species at the Pakistan Margin: evidence from stable isotopes and lipid biomarkers. 
Deep-Sea Res I 56:1816-1833

Kamykowski D, Zentara SJ (1990) Hypoxia in the world ocean as recorded in the historical data set. Deep-Sea Res I 37:1861-1874

Karlson AML, Nascimento FJA, Naslund J, Elmgren R (2010) Higher diversity of deposit-feeding macrofauna enhances phytodetritus processing. Ecology 91:1414-1423

> Kattner G, Hagen W (1998) Lipid metabolism of the Antarctic euphausiid Euphausia crystallorophias and its ecological implications. Mar Ecol Prog Ser 170:203-213

Kiriakoulakis K, Stutt E, Rowland S, Vangriesheim A, Lampitt R, Wolff G (2001) Controls on the organic chemical composition of settling particles in the Northeast Atlantic Ocean. Prog Oceanogr 50:65-87

Kiriakoulakis K, Bett BJ, White M, Wolff GA (2004) Organic biogeochemistry of the Darwin Mounds, a deep-water coral ecosystem, of the NE Atlantic. Deep-Sea Res I 51: 1937-1954

Laakmann S, Kochzius M, Auel H (2009) Ecological niches of Arctic deep-sea copepods: vertical partitioning, dietary preferences and different trophic levels minimize inter-specific competition. Deep-Sea Res I 56:741-756

> Lamont P, Gage J (2000) Morphological responses of macrobenthic polychaetes to low oxygen on the Oman continental slope, NW Arabian Sea. Deep-Sea Res II 47:9-24

Larkin KE (2006) Community and trophic responses of benthic Foraminifera to oxygen gradients and organic enrichment. PhD dissertation, University of Southampton, p 154-187

> Larkin KE, Gooday AJ (2009) Foraminiferal faunal responses to monsoon-driven changes in organic matter and oxygen availability at 140 and $300 \mathrm{~m}$ water depth in the NE Arabian Sea. Deep-Sea Res II 56:403-421

Levin LA (2003) Oxygen minimum zone benthos: adaptation and community response to hypoxia. Oceanogr Mar Biol Annu Rev 41:1-45

> Levin L, Edesa S (1997) The ecology of cirratulid mudballs on the Oman margin, northwest Arabian Sea. Mar Biol 128:671-678

> Levin LA, Huggett CL, Wishner KF (1991) Control of deepsea benthic community structure by oxygen and organicmatter gradients in the Eastern Pacific Ocean. J Mar Res 49:763-800

Levin LA, Blair N, DeMaster D, Plaia G, Fornes W, Martin C (1997) Rapid subduction of organic matter by maldanid polychaetes on the North Carolina Slope. J Mar Res 55: 595-611

> Levin L, Gage J, Martin C, Lamont P (2000) Macrobenthic community structure within and beneath the oxygen minimum zone, NW Arabian Sea. Deep-Sea Res II 47: $189-226$

Levin L, Gutiérrez D, Rathburn A, Neira C (2002) Benthic processes on the Peru margin: a transect across the oxygen minimum zone during the 1997-98 El Niño. Prog Oceanogr 53:1-27

> Levin LA, Rathburn AE, Gutiérrez D, Muñoz P, Shankle A (2003) Bioturbation by symbiont-bearing annelids in near-anoxic sediments: implications for biofacies models and paleo-oxygen assessments. Palaeogeogr Palaeoclimatol Palaeoecol 199:129-140

> Levin LA, Ekau W, Gooday AJ, Jorissen F and others (2009a) Effects of natural and human-induced hypoxia on coastal benthos. Biogeosciences 6:2063-2098

> Levin LA, Whitcraft CR, Mendoza GF, Gonzalez JP, Cowie G (2009b) Oxygen and organic matter thresholds for ben- thic faunal activity on the Pakistan margin oxygen minimum zone (700-1100 m). Deep-Sea Res II 56:449-471

Loick N, Ekau W, Verheye HM (2005) Water-body preferences of dominant calanoid copepod species in the Angola-Benguela frontal zone. Afr J Mar Sci 27:597-608

Loreau M, Naeem S, Inchausti P, Bengtsson J and others (2001) Biodiversity and ecosystem functioning: current knowledge and future challenges. Science 294:804-808

McCutchan J, Lewis W, Kendall C, McGrath C (2003) Variation in trophic shift for stable isotope ratios of carbon, nitrogen, and sulfur. Oikos 102:378-390

> Middelburg JJ, Levin LA (2009) Coastal hypoxia and sediment biogeochemistry. Biogeosciences 6:1273-1293

> Murty SJ, Bett BJ, Gooday AJ (2009) Megafaunal responses to strong oxygen gradients on the Pakistan margin of the Arabian Sea. Deep-Sea Res II 56:472-487

> Nascimento FJA, Karlson AML, Naslund J, Elmgren R (2011) Diversity of larger consumers enhances interference competition effects on smaller competitors. Oecologia 166:337-347

Neira C, Gad G, Arroyo NL, Decraemer W (2001) Glochinema bathyperuvensis sp n. (Nematoda, Epsilonematidae): a new species from Peruvian bathyal sediments, SE Pacific Ocean. Contrib Zool 70:147-159

Neira C, Decraemer W, Backeljau T (2005) A new species of Glochinema (Epsilonematidae: Nematoda) from the oxygen minimum zone off Baja California, NE Pacific and phylogenetic relationships at species level within the family. Cah Biol Mar 46:105-126

Nelson MM, Mooney BD, Nichols PD, Phleger CF (2001) Lipids of Antarctic Ocean amphipods: food chain interactions and the occurrence of novel biomarkers. Mar Chem 73:53-64

- Nomaki H, Ogawa N, Ohkouchi N, Suga H and others (2008) Benthic foraminifera as trophic links between phytodetritus and benthic metazoans: carbon and nitrogen isotopic evidence. Mar Ecol Prog Ser 357:153-164

- Norling K, Rosenberg R, Hulth S, Gremare A, Bonsdorff E (2007) Importance of functional biodiversity and speciesspecific traits of benthic fauna for ecosystem functions in marine sediment. Mar Ecol Prog Ser 332:11-23

Palma M, Quiroga E, Gallardo V, Arntz W, Gerdes D, Schneider W, Hebbeln D (2005) Macrobenthic animal assemblages of the continental margin off Chile $\left(22^{\circ}\right.$ to $\left.42^{\circ} \mathrm{S}\right)$. J Mar Biol Assoc UK 85:233-245

$>$ Pfannkuche O, Lochte K (2000) The biogeochemistry of the deep Arabian Sea: overview. Deep-Sea Res II 47: 2615-2628

Pond D, Allen C, Bell M, Van Dover C, Fallick A, Dixon D, Sargent J (2002) Origins of long-chain polyunsaturated fatty acids in the hydrothermal vent worms Ridgea piscesae and Protis hydrothermica. Mar Ecol Prog Ser 225: 219-226

Post D (2002) Using stable isotopes to estimate trophic position: models, methods, and assumptions. Ecology 83: 703-718

Qasim SZ (1982) Oceanography of the northern Arabian Sea. Deep-Sea Res I 29:1041-1068

Rabalais NN, Turner RE, Diaz RJ, Justic D (2009) Global change and eutrophication of coastal waters. ICES J Mar Sci 66:1528-1537

Robinson JL, Cavanaugh CM (1995) Rubisco in chemoautotrophic symbioses: implications for the interpretation of stable carbon isotope values. Limnol Oceanogr 40: 1496-1502 
Rosa R, Seibel B (2010) Metabolic physiology of the Humboldt squid, Dosidicus gigas: implications for vertical migration in a pronounced oxygen minimum zone. Prog Oceanogr 86:72-80

Sarmiento J, Herbert T, Toggweiler J (1988) Causes of anoxia in the world ocean. Global Biogeochem Cycles 2: $115-128$

Smallwood B, Wolff G, Bett B, Smith C, Hoover D, Gage J, Patience A (1999) Megafauna can control the quality of organic matter in marine sediments. Naturwissenschaften 86:320-324

Solan M, Cardinale BJ, Downing AL, Engelhardt KAM, Ruesink JL, Srivastava DS (2004) Extinction and ecosystem function in the marine benthos. Science 306: $1177-1180$

Solan M, Batty P, Bulling MT, Godbold JA (2008) How biodiversity affects ecosystem processes: implications for ecological revolutions and benthic ecosystem function. Aquat Biol 2:289-301

Stevens CJ, Limen H, Pond DW, Gelinas Y, Juniper SK (2008) Ontogenetic shifts in the trophic ecology of two alvinocaridid shrimp species at hydrothermal vents on the Mariana Arc, western Pacific Ocean. Mar Ecol Prog Ser 356:225-237

Stramma L, Schmidtko S, Levin L, Johnson G (2010) Ocean oxygen minima expansions and their biological impacts. Deep-Sea Res I 57:587-595

Svetlichny L, Hubareva E, Erkan F, Gucu A (2000) Physiological and behavioral aspects of Calanus euxinus females (Copepoda: Calanoida) during vertical migration across temperature and oxygen gradients. Mar Biol 137:963-971

Svetlichny L, Kideys A, Hubareva E, Besiktepe S, Isinibilir M (2006) Development and lipid storage in Calanus euxinus from the Black and Marmara seas: variabilities due to habitat conditions. J Mar Syst 59:52-62

Editorial responsibility: Hans Heinrich Janssen, Oldendorf/Luhe, Germany
Walton MJ, Pennock JF (1972) Some studies on biosynthesis of ubiquinone, isoprenoid alcohols, squalene and sterols by marine invertebrates. Biochem J 127:471-479

Wishner KF, Ashjian CJ, Gelfman C, Gowing MM and others (1995) Pelagic and benthic ecology of the lower interface of the Eastern Tropical Pacific Oxygen Minimum Zone. Deep-Sea Res I 42:93-115

Wishner KF, Gowing MM, Gelfman C (1998) Mesozooplankton biomass in the upper $1000 \mathrm{~m}$ in the Arabian Sea: overall seasonal and geographic patterns, and relationship to oxygen gradients. Deep-Sea Res II 45:2405-2432

- Wishner KF, Gowing MM, Gelfman C (2000) Living in suboxia: ecology of an Arabian Sea oxygen minimum zone copepod. Limnol Oceanogr 45:1576-1593

> Wishner KF, Gelfman C, Gowing MM, Outram DM, Rapien M, Williams R (2008) Vertical zonation and distributions of calanoid copepods through the lower oxycline of the Arabian Sea oxygen minimum zone. Prog Oceanogr 78: 163-191

Wootton JAM, Wright LD (1962) A comparative study of sterol biosynthesis in Annelida. Comp Biochem Physiol $5: 253-264$

> Woulds C, Cowie GL (2009) Sedimentary pigments on the Pakistan margin: controlling factors and organic matter dynamics. Deep-Sea Res II 56:347-357

Woulds C, Cowie GL, Levin LA, Andersson JH and others (2007) Oxygen as a control on sea floor biological communities and their roles in sedimentary carbon cycling. Limnol Oceanogr 52:1698-1709

Woulds C, Andersson JH, Cowie GL, Middelburg JJ, Levin LA (2009) The short-term fate of organic carbon in marine sediments: comparing the Pakistan margin to other regions. Deep-Sea Res II 56:393-402

Zettler M, Bochert R, Pollehne F (2009) Macrozoobenthos diversity in an oxygen minimum zone off northern Namibia. Mar Biol 156:1949-1961

Submitted: December 15, 2011; Accepted: August 24, 2012 Proofs received from author(s): November 22, 2012 